\title{
Proteome Exploration of Legionella pneumophila for Identifying Novel Therapeutics: A Hierarchical Subtractive Genomics and Reverse Vaccinology Approach
}

\section{Authors:}

Md Tahsin Khan ${ }^{1}$, Araf Mahmud ${ }^{1}$, Mahmudul Hasan², Kazi Faizul Azim³ ${ }^{3}$, Musammat Kulsuma Begum $^{1}$, Arzuba Akter ${ }^{4}$, Shakhinur Islam Mondal ${ }^{1}{ }^{*}$

\author{
Affiliations: \\ ${ }^{I}$ Department of Genetic Engineering and Biotechnology, Shahjalal University of Science and \\ Technology, Sylhet-3114, Bangladesh \\ ${ }^{2}$ Department of Pharmaceuticals and Industrial Biotechnology, Sylhet Agricultural University, \\ Sylhet-3100, Bangladesh \\ ${ }^{3}$ Department of Microbial Biotechnology, Sylhet Agricultural University, Sylhet-3100, \\ Bangladesh \\ ${ }^{4}$ Department of Biochemistry and Molecular Biology, Shahjalal University of Science and \\ Technology, Sylhet-3114, Bangladesh
}

\section{*Corresponding author}

Dr Md Shakhinur Islam Mondal

Associate Professor

Department of Genetic Engineering and Biotechnology, Shahjalal University of Science and Technology, Sylhet-3114, Bangladesh

Email: shakhin200-gen@ sust.edu

Phone: +353-894440254 


\begin{abstract}
Legionella pneumophila, the causative agent of a serious type of pneumonia (lung infection) called Legionnaires' disease. It is emerging as an antibacterial resistant strain day by day. Hence, the identification of novel drug targets and vaccine candidates is essential to fight against this pathogen. Herein attempts were taken through subtractive genomics approach on complete proteome of L. pneumophila to address the challenges of multidrug resistance. A total 2930 proteins from L. pneumophila proteome were investigated through diverse subtractive proteomics approaches, e.g., identification of human non-homologous and pathogen-specific essential proteins, druggability and 'anti-target' analysis, prediction of subcellular localization, human microbiome non-homology screening, protein-protein interactions studies in order to find out effective drug and vaccine targets. Only 3 were identified that fulfilled all these criteria and proposed as novel drug targets against L. pneumophila. Furthermore, outer membrane protein TolB was identified as potential vaccine target with better antigenicity score and allowed for further in silico analysis to design a unique multiepitope subunit vaccine against it. Antigenicity and transmembrane topology screening, allergenicity and toxicity assessment, population coverage analysis, and molecular docking approach were adopted to generate the most potent epitopes. The final vaccine was constructed by the combination of highly immunogenic epitopes along with suitable adjuvant and linkers. The designed vaccine construct showed higher binding interaction with different MHC molecules and human immune TLR2 receptors with minimum deformability at molecular level. The translational potency and microbial expression of the vaccine protein was also analyzed using $\mathrm{pET} 28 \mathrm{a}(+)$ vector. The present study aids in the development of novel therapeutics and vaccine candidates for efficient treatment of the infections caused by Legionella pneumophila. However, further wet lab-based investigations and in vivo trials are highly recommended to experimentally validate our prediction.
\end{abstract}

Keywords: Legionnaires' disease; Legionella pneumophila; Subtractive genomics; Reverse vaccinology; Protein-protein docking; Molecular dynamics; In silico cloning 


\section{Introduction}

Legionella pneumosphila is a human pathogen that is distributed worldwide within freshwater and biofilms. [1]. Inhalation of Legionella spp. cause Legionnaires' disease (LD), a severe form of pneumonia and respiratory tract infection [2] and about $90 \%$ are caused by L. pneumophila species [3]. L. pneumophila belongs to the responsibility of maximum incidences regarding water-associated diseases in the United States [4,5] and caused approximately half of all reported waterborne disease outbreaks in 2005-2006 [no6,7]. L. pneumophila was declared as an important pathogen by the US Environmental Protection Agency (EPA) Candidate Contaminant List (CLL) due to the prevalence and seriousness of its effects on disease causing [8]. In case of disease progression, Icm/Dot type IVb secretion systems are used by Legionella spp in order to translocate a large repertoire of effector proteins inside the host cell cytosol [9-13], which modulate the fate of phagocytic vacuoles by preventing the fusion of phagosome-lysosome along with vacuole acidification, and by recruiting vesicles that delegate on it the properties of the endoplasmic reticulum [14]. Bacteria then damage, even completely destroy the host cell after the proliferation in this compartment.

The emergence of resistance against antibiotics or a combination of antibiotics of various infectious agents poses global threats in human health [15]. At present, the majority of pathogens causing infectious diseases are resistant to more than one drug [16]. Recent epidemiological research found L. Pneumophila strains display a high prevalence of tolerance (50\%-100\%) to widely used antibiotics comprising azithromycin, ceftriaxone, rifampicin, tigecycline, ciprofloxacin, moxifloxacin, doxycycline, erythromycin, levofloxacin and clarithromycin[17,18]. This emphasizes the urgency of developing new therapeutic antibacterial agents directing towards novel targets $[15,19]$. Therefore, it is exigent to identify novel therapeutic targets of $L$. pneumophila.

Identification of novel drug targets and vaccine candidates leads to drug and therapeutics component designing. The disease-based approach of the traditional method of drug discovery is both expensive, and time-consuming since significant time and devoted researchers are required 
to identify potential ligands. In recent years, computational aided drug targets discovery methods reduce consumption of time by eliminating compounds in this process that have a limited chance of success [20,21,22,23]. Among various computational methods and strategies, subtractive genomic analysis can be regarded worthy since data regarding genome and proteome are available in various online based databases. Subtractive and comparative microbial genomics are being used for the identification of targets in a number of human pathogens like M. tuberculosis [24], Burkholderia pseudomalleii [25], Helicobacter pylori [26] Pseudomonas aeruginosa [27], Neisseria gonorrhea [28] and Salmonella typhi [29]. In case of targeting genes or proteins for drug targets through subtractive and comparative microbial genome analysis, the main theme is to find such targets (gene/protein) that are essential for the pathogen and possess no homology counterpart in the host [30]. Along with subtractive genomics approach, reverse vaccinology strategy optimizes the prediction and development of novel drug and vaccine targets, especially for microorganisms that are difficult to grow in the laboratory, such as intracellular bacteria including L. pneumophila. Conventional vaccines may take more than 15 years to develop relying on adequate antigen expression from in vitro culture models including undesirable consequences while epitope-based vaccine prediction could be a faster approach targeting immunogenic protein through entire bacterial or viral proteome [31-33]. Reverse vaccinology approach usually identified a protein vaccine candidate using defined features, such as protein subcellular localization, topology, adhesion/antigenicity probability, epitopes, and its binding to the major histocompatibility complex (MHC) class I and II molecule [34]. Reverse vaccinology approach has been proven to prioritize and design vaccine targets against multiple pathogens [35-39].

In this study, we took in-depth subtractive genomics and reverse vaccinology approach to identify novel therapeutic drug and vaccine target in L. pneumophila subsp. pneumophila (strain Philadelphia 1 / ATCC 33152 / DSM 7513). We particularly considered the key essential or survival proteins of the pathogen which are non-homologous to the host as well as host microbiota and screened for outer membrane proteins (OMP) and B/T-cell epitopes. At the same time, we performed the human microbiome non-homologous analysis. The highest scoring OMP's and epitopes will facilitate future in vitro and in vivo tests for the production of drugs and suitable vaccine against intracellular L. pneumophila infection. 


\section{Materials and methods}

The genome-wide proteome exploration of L. pneumophila was employed for identifying novel drug and vaccine targets through subtractive genomics and reverse vaccinology approach. The overall workflow has been illustrated in Fig. 1 and Fig. 2.

\section{Proteome retrieval and Finding paralogous sequences}

The entire proteome of L. pneumophila subsp. pneumophila (strain Philadelphia 1 / ATCC 33152 / DSM 7513) (UniProt ID: UP000000609), was retrieved from UniProt(http://www.uniprot.org/proteomes/) containing total 2930 proteins [40] which were subjected to CD-Hit analysis (http://weizhongli-lab.org/cdhit_suite/cgi-bin/index.cgi?cmd=cdhit) [41]. Sequence identity cutoff score was set at 0.6 to exclude redundant sequences of more than $60 \%$ identity through this method. Only non-paralogous protein sequences excluding the redundant sequences (paralogous sequences) were passed through further study.

\section{Identification of human (host) non-homologous proteins}

The goal of the non-homology analysis of L. pneumophila subsp. pneumophila is to identify pathogen specific-proteins which are non-homologous to the human. BLASTp analysis was carried out on non-paralogous proteins against the reference proteome of Homo sapiens using threshold expectation value (E value) $10^{-3}$ through Ensembl (https://uswest.ensembl.org/Multi/Tools/Blast?db=core) [42]. Proteins that showed significant hits were filtered out meaning that they had similarities with the human genome leaving just the nonhomologous sequences. These non-homologous sequences were screened. The purpose of this step is to avoid any functional resemblance with human proteomes and to reduce any unwanted cross-reactivity of the drugs thereby avoiding the binding of drugs to the active site of homologous human proteins [43]. 


\section{Identification of essential nonhomologous proteins}

Nonhomologous proteins were subjected to Database of Essential Genes (DEG) [44]. DEG contains 53,885 essential genes and 786 essential non-coding sequences. BLASTp of previously selected nonhomologous proteins was carried out by selecting all the organisms present in DEG 15.2 server and using threshold expectation value $10^{-10}$, a minimum bit-score cut-off of 100 as parameters, but the hits with e-value $\leq 10^{-100}$, identity $\geq 25 \%$, and same annotated function of the query was selected as essential proteins. These essential proteins were employed for further study. Proteins of essential genes in a bacterium shape a minimal genome, containing a set of functional modules that play key roles in the evolving area, synthetic biology [44].

\section{Metabolic pathway analysis and family prediction of hypothetical proteins}

Kyoto Encyclopedia of Genes and Genomes [KEGG] includes full metabolic pathways in living organisms [45]. Using three letter KEGG organism code hsa and lpn of human and Legionella pneumophila subsp. Pneumophilarespectively, all the metabolic pathways present in the host ( $H$. sapiens) and the pathogen were collected separately. A manual comparison was made to identify the metabolic pathways that were only present in the pathogen, as unique to Legionella pneumophila subsp. pneumophila using KEGG PATHWAY Database [46] whereas the remaining pathways were grouped as common. The predicted human nonhomologous, essential proteins of Legionella pneumophila subsp.pneumophila were screened by BLASTp through KAAS [47] server at KEGG for the identification of potential drug and vaccine targets. KAAS (KEGG Automatic Annotation Server) generates functional annotation of genes by BLAST comparisons against the manually compiled KEGG GENES database and metabolic proteins are listed by assignments of KO (KEGG Orthology). It automatically generates KEGG pathways which indicate certain metabolic proteins. For the next phase of subcellular localization study, proteins involved in these particular metabolic pathways of the pathogen and proteins allocated to $\mathrm{KO}$ but not involved in specific pathways, were identified, except those proteins involved in common human and pathogen pathways. SVMProt is a server that uses Support Vector Machine to identify a protein sequence from its primary sequence into a specific class that contains all major groups of enzymes, transporters, receptors, pathways, RNA- binding and DNA- binding 
proteins. TheSVMProt server[48] (http:/bidd2.nus.edu.sg/cgi-bin/svmprot/svmprot.cgi) was used to determine the functional classes of the pathogen's specific metabolic proteins in all uncharacterized, hypothesized proteins.

\section{Prediction of subcellular localization}

For the reasons of gram-negativity, Legionella pneumophila subsp. proteins can be identified in five viable subcellular locations, such as cytoplasm, inner membrane, periplasm, outer membrane and extracellular. Cytoplasmic proteins can be used as targets for medications while surface membrane proteins can be used as targets for both the medication and vaccine[49].

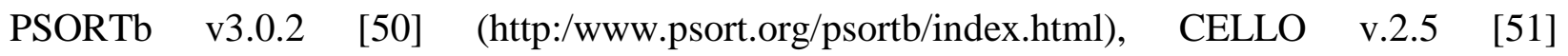
(http:/cello.life.nctu.edu.tw/), ngLOC (http:/genome.unmc.edu/ngLOC/index.html) was used to predict the location of selected non-homologous essential pathogen proteins. The best score for a location was counted, generated by these servers. Final location of these proteins was taken through three steps: 1) if all three servers predicted the same location for a protein, that location was selected as final result, 2) if any two of these three servers predict the same location for a protein, that location was selected as final result, 3) if they predicted three different locations for a protein then PSLpred server [52] (http://crdd.osdd.net/raghava/pslpred/) was used and the predicted location for that protein done through PSLpred server was matched with previous results predicted by PSORTb v3.0.2, CELLO v.2.5, and ngLOC servers.

\section{Druggability Screening and antigenicity analysis}

DrugBank Database 5.1.0 contains entries including 2556 approved small molecule drugs, 962 licensed pharmaceutical drugs, 112 nutraceuticals, and more than 5125 experimental drugs. In addition, 5117 non-redundant protein sequences (i.e. drug target / enzyme / carrier / transporter) are linked to these drug entries. A 'druggable' target must have the potential to bind to drugs and drug-like molecules with high affinity. Shortlisted cytoplasmic and membrane proteins were screened through the database of DrugBank 5.1.0[53] using default parameters. Presence of drug targets from the shortlisted cytoplasmic and membrane proteins in DrugBank database indicating 
same biological functions can act as an evidence for their druggable properties and were grouped as current therapeutic targets while their absence indicated the novelty of those drug targets, hence were classified as 'novel therapeutic targets'. Total 45 proteins that showed no similarity after passed through DrugBank database were listed as novel drug targets and vaccine candidates. VaxiJen v2.0 [54] was used for predicting the protective antigens and subunit vaccines. Only membrane protein sequences of novel drug targets of Legionella pneumophila subsp. Pneumophila were subjected to VaxiJen v2.0 selecting threshold value 0.4. Proteins that showed antigenicity prediction $>0.4$ in VaxiJen v2.0 were transferred for next step as potential vaccine candidates.

\section{'Anti-target' analysis of the essential, nonhomologous and novel drug targets}

For humans, the human Ether-a-go-go Related Gene (hERG), constitutive androstane receptor $(\mathrm{CAR})$, pregene $\mathrm{X}$ receptor (PXR), and P-glycoproteins (P-gp) are anti-targets or alternative drug targets for host protein candidates. Some receptive membrane are aelso classified as 'anti-target'. they are adrenergic $\alpha 1 \mathrm{a}$, dopaminergic D2, muscarinic M1, and serotonergic 5-HT2C. A total of 210 human 'anti-targets' have been identified in the literature (Supplementary file S1)[11] and the corresponding sequences of these proteins have been obtained from the NCBI Protein database. BLASTp was carried out for all nonhomologous, essential 'novel drug target' proteins against these 'anti-targets' setting an E-value threshold $<0.005$, query length $>30 \%$, identity $<30 \%$ as parameters. Nonhomologous proteins showing $<30 \%$ identity against these 'anti-target' proteins were transferred to next step.

\section{Human microbiome non-homology analysis}

The correlation between gut flora and human is not merely commensal but rather is symbiotic, mutualistic relationship [59], and different beneficial functions by human microbiome were also been reported [60,61].Unintentional blocking or accidental inhibition of proteins present in thismicroflora may lead to adverse effects in the host [62]. Screening of nonhomologous, essential proteins selected as vaccine candidates and novel drug targets were subjected to 
BLASTp through NCBI protein blast server (https://blast.ncbi.nlm.nih.gov/Blast.cgi) using an Evalue 'cutoff score 1' against the dataset present in Human Microbiome Project server (https://www.hmpdacc.org/hmp/) "43021 (BioProject)" [63] was mentioned in the Entrez Query field while selecting Non-redundant protein sequences (nr) as the database. The Human Microbiome Project (HMP) collected microbial strains from a disease-free, stable, 239-person adult population, which included 18 body habitats in five areas (oral, skin, nasal, gut, and urogenital), creating 5026 microbial species compositions[64]. Proteins showing < 48\% similarity were identified as novel therapeutic targets and vaccine candidates and moved to the next stage. The results of this screening study ensured the chance to prevent unintended inhibition and unconscious blockage of human microflora proteins.

\section{Protein-Protein Interaction studies}

The protein-protein interaction studies (PPIs) of selected shortlisted proteins were predicted using STRING v10.5 [65]. The database identifies both physical (direct) and functional (indirect) interactions. PPIs with high confidence score $(\geq 70 \%)$ were considered to avoid false positive results. Inhibition of essential proteins can hamper other proteins to perform correctly. Therefore, analysisof PPIs of the shortlisted proteins with others of the same strain can help to identify the best therapeutic targets. Proteins showing close interactions with at least three others were selected for further studies. Only outer membrane protein with antigenicity score $>0.6$ was transferred to the next stage for reverse vaccinologyafter homology modeling and validation step and the rests were listed as probable novel drug targets.

\section{Homology modeling, structure optimization and validation}

Since no exact PDB structure was available for the selected proteins, a BLASTp was carried out in NCBI for each protein where Protein Data Bank Proteins (pdb) was selected as the Database. The templates were chosen for homology modeling considering sequence identity $\geq 85$ and query cover $\geq 30$. EasyModeller 4.0 software was used to generate the best $3 \mathrm{D}$ structure of each selected therapeutic proteins[66]. The best models were subjected to ModRefiner for energy minimization and structure refinement [67]. Root mean square deviation (RMSD) values were also calculated. Evaluation of the optimized, refined structures was carried through online 
servers, PROCHECK [68] and ERRAT [69] present in Structural Analysis and Verification Server (SAVES) (http://servicesn.mbi.ucla.edu/SAVES/) to get the stereochemical quality of the model.

\section{Antigenic protein selection and T-Cell epitope prediction}

Among the membrane associated proteins, the final vaccine target was selected according to protein-protein interaction analysis and antigenicity. ProtParam [70] tool showed different physico-chemical parameters of the proteins. The IEDB MHC-I and MHC-II prediction tools were used to predict MHC-I and MHC-II binding peptides, respectively. [71].

Transmembrane topology, antigenicity, population coverage and allergenicity assessment of T-Cell epitopes

The TMHMM server predicted transmembrane helices in protein[72], while the VaxiJen v2.0 server was used to test antigenicity of the epitopes[54]. Population coverage has been evaluated for each human epitope using an IEDB analysis tool[70]. Four independent servers i.e. AllerTOP[73], AllergenFP[74], PA3P[75], and Allermatch[76] have been used to estimate epitope allergicity for potential vaccine design.

\section{Toxicity and conservancy analysis}

The server ToxinPred (http:/crdd.osdd.net/raghava/toxinpred/) estimated the relative toxicity of top T-cell epitopes. Conservancy of the epitope has been shown to determine the degree of distribution in the homologous protein set of corresponding epitopes using the IEDB epitope conservancy analysis tool (http:/tools.iedb.org/conservancy/).

\section{Identification of B-Cell epitopes and cluster analysis}

Six separate IEDB algorithms, that is. The Kolaskar and Tongaonkar antigenicity scale[77], the Karplus and Schulz versatility prediction[78], the Chou and Fasman beta turn prediction[79], the 
Emini surface accessibility prediction[80], the Parker hydrophilicity prediction[81] and the Bepipred linear epitope prediction tool[82] were used to identify the most active B cell epitopes in the target protein. Additionally, an analysis tool for the IEDB epitope cluster was used to identify overlapping peptides among the predicted epitopes[83]. Between top epitopes of CTL, HTL and BCL, larger cassettes containing multiple epitopes were found.

\section{Final vaccine construction}

The final vaccine was formulated using the top epitopes (T-cell and B-cell), the adjuvants and the corresponding linkers. Three specific adjuvants, i.e. beta-defensin, ribosomal protein L7/L12 and M. Tuberculosis HABA protein (AGV15514.1) has been used to produce three separate vaccine molecules. Adjuvants interact with toll-like receptors (TLRs) and cause immune activation by polarizing CTL reactions[84]. Beta defensin adjuvant is TLR1, 2 and 4 agonist, whereas L7/L12 ribosomal protein and HBHA protein act only as TLR4 agonist. EAAAK, GGGS, GPGPG and KK linkers have been used to bind the adjuvant, CTL, HTL and B-cell epitopes, respectively. Literature reports also state that linkers allow efficient in vivo separation of individual epitopes[85,86]. To that the problem with highly polymorphic HLAs, the PADRE sequence was also inserted into vaccine constructs.

\section{Allergenicity, antigenicity, physico-chemical property and secondary structure analysis of vaccine constructs}

AlgPred v.2.0 [87] sever was used to predict the non-allergic nature of the constructed vaccines. In order to suggest the superior vaccine candidate, VaxiJen v2.0 server[54] was used to evaluate its antigenicity. ProtParam[70,88] has shown molecular weight, instability index, approximate half-life, isoelectric pH, GRAVY values, hydropathicity, aliphatic index and other physicochemical properties of the constructs. The secondary structure of the vaccine protein was determined by PSIPRED v3.3[89] and NetTurnP v1.0 [90,91].

\section{Vaccine tertiary structure prediction, refinement, validation and disulfide engineering}

The RaptorX server generated the tertiary structure of the constructs based on the degree of similarity between target protein and accessible template structure in PDB database[92,93]. 
Refinement was conducted using ModRefiner [94] followed by FG-MD refinement server [95] to improve the accuracy of the predicted 3D modeled structure. Ramachandran plot of the refined structure was assessed by RAMPAGE [96]. Disulfide bonds enhance the geometric conformation of proteins and provide significant stability. DbD2 was used to build these bonds for the vaccine designs [97]. The value of chi3 selected for the residue screening was -87 to +97 , while the energy value considered was less than 2.5 .

\section{Protein-protein docking and molecular dynamics simulation}

Inflammations caused by bacterial antigen are involved with TLR-2 immune receptors present over the immune cells [98-100]. The 3D structure of different MHC molecules and human TLR2 receptors has been obtained from the database of RCSB proteins. Molecular docking method using ClusPro[101], hdoc[102,103] and PatchDock server[104] determined the binding affinity of designed vaccines with specific HLAs and TLR-2 immune receptors. FireDock server refined the complexes generated via PatchDock server [104]. The vaccine-receptor complex's stability was determined by contrasting the critical protein dynamics to their normal modes[105,106]. Essential dynamics is a versatile tool and an inexpensive solution to costly atomistic simulation [106,107]. iMODS server explained the collective motion of the proteins by analyzing the normal modes (NMA) in internal coordinates [108,109]. The server was used as it assess much faster than other molecular dynamics simulations tools [110,111]. The direction and extent of the immanent motions of the complex was analyzed in terms of B-factors, deformability, covariance and eigenvalue [112].

\section{Codon adaptation and in silico cloning}

For greater expression of the vaccine protein in E. coli, a codon adaptation technique was used. The procedure was conducted by the JCAT server[113], while preventing the termination of Rho's independent transcription, the ribosome-binding prokaryote site, and the cleavage of several other restriction enzymes (i.e. HindIII and BamHI). The optimized sequence of vaccine protein V1 was reversed and then conjugated with HindIII and BamHI restriction site at the N- 
terminal and C-terminal sites respectively. SnapGene restriction cloning module was used to insert the adapted sequence between HindIII (173) and BamHI (198) of pET28a(+) vector [114].

\section{Results}

All the methodologies used in the proteome exploration of Legionella pneumophila including the number of proteins screened in each step had been summarized in Table 1.

\section{Proteome retrieval and Finding paralogous sequences}

The whole proteome retrieved from UniProt (UniProtID: UP000000609) containing 2930 proteins were analyzed in $\mathrm{CD}$-Hit tool using threshold value 0.6 to eliminate paralogous and duplicate sequences showing $>60 \%$ sequence identity. Paralogous protein sequences were removed leaving total 2878 non-paralogous protein sequences.

\section{Identification of human non-homologous proteins}

Non-paralogous protein sequences were screened by BLASTp through Ensembl genome browser 92868 proteins was found showing similarity with the human genome which were excluded leaving total 2010 non-homologous proteins.

\section{Identification of essential proteins}

Among 2010 nonhomologous proteins, only 125 protein sequences showed similarity with the essential proteins enlisted in DEG server from 48 bacterial strains. These 125 proteins were listed as essential proteins and are considered as responsible for the survival of Legionella pneumophila. 


\section{Metabolic pathway analysis and family prediction of hypothetical proteins}

Though 120 pathways of target Legionella pneumophila were identified from KEGG server, only 37 pathways were detected as unique for pathogen (Supplementary file S2). The result from KAAS server at KEGG revealed that 122 proteins among 125 had assigned KO identifier. From 122, only 4 proteins were involved in unique metabolic pathways (Table 2) and 29 proteins involved neither in unique nor common pathways (Supplementary Table 1). Only 3 hypothetical proteins were found among these $29 \mathrm{KO}$ assigned proteins for which functions remains unknown. Functional family for these hypothetical proteins were also analyzed (Supplementary Table 2). All of these 33 proteins were allowed for further investigation. Remaining 89 proteins were excluded since these were found to be involved in both pathogen and human metabolic pathways.

\section{Prediction of subcellular localization}

The shortlisted 33 nonhomologous essential proteins involved in unique pathways of the pathogen were screened through PSORTb, CELLO and ngLOC servers. A total 16 proteins were identified as cytoplasmic proteins and 16 proteins were identified as membrane proteins which were further screened for druggability and antigenicity analysis (Supplementary file S3). But, the study failed to predict the subcellular localization of 'tr|Q5ZYU2' since these four servers generated different predictions.

\section{Druggability Screening and antigenicity analysis}

Only 7 proteins showed similarity with the available drug targets (Table 3) at DrugBank5.1.0 database. The remaining 25 showed no hitand thesewere considered as novel drug targets of $L$. 
pneumophila which were comprised of 13 cytoplasmic and 12 membrane proteins. Antigenicity analysis of membrane protein revealed that only 1 protein was non antigenic whereas the rest 11 showed antigenicity score more than 0.4. at VaxiJen server (Table 4). Furthermore, all of the proteins screened after druggability and antigenicity analysis were employed for human 'antitargets' and microbiome non-homology study.

\section{'Anti-target' and Human microbiome non-homology analysis}

To avoid severe cross-reaction and toxic effects in human, identification of nonhomologous proteins to human essential proteins (referred as 'anti-targets') is a crucial step. Study revealed that all selected 25 novel therapeutic proteins showed no similarity with 210 human 'anti-targets'. In addition, BLASTp against all microbial strains presented in Human Microbiome Project (HMP) server carried out through NCBI blast server revealed that only 5 proteins out of 25 showed similarity $\leq 47 \%$ (Table 5). Targeting these proteins will be suitable since they are neither involved in common pathways of host-pathogen nor homologous to any human 'antitargets'.

\section{Protein-Protein Interaction studies}

PPIs in STRING v10.5 revealed that Cytoplasmic protein 'UDP-N-acetylmuramoyl-L-alanyl-Dglutamate--2,6-diaminopimelate ligase (murE)' showed interactions with proteins involved in cell wall biosynthesis pathways (Fig. 3A) whereas 'Trigger factor (tig)' showed interactions with proteins which were mainly involved in binding with different rRNA and tRNA molecules (Fig. 3B). Moreover, inner membrane protein 'Probable lipid II flippaseMurJ (mviN)' exhibited interactions with proteins which were connected to peptidoglycan biosynthesis pathway and transportation of lipid-linked peptidoglycan precursors (Fig. 3C), where 'Biotin synthase (bioB)' is an essential protein for the survival of pathogen. The name of essential drug targets listed in Table 6. Another inner membrane protein 'Probable potassium transport system protein kup 1 (kup1)' presented single interaction (Fig. 3D) and as a consequence it was excluded from our analysis. Moreover, the remaining outer membrane protein 'TolB (tolB)' showed close 
interactions with different other proteins (Fig. 3E) which were mainly found in peptidoglycan synthesis and lipoproteins translocation process. 'Protein TolB' also exhibited less similarity $(<47 \%)$ with human microflora proteins and had antigenicity score $>0.6$, that is why, it had been considered as potential vaccine candidate against Legionella pneumophila. So, further study was employed for 'in silico vaccine design' focusing 'Protein TolB' by reverse vaccinology approach. Details of PPIs was provided in Supplementary file S4.

\section{Homology modeling, structure optimization and validation}

The selected single vaccine candidate Q5ZV69 was modeled to determine 3D structure through EasyModeller 4.0 (Supplementary Fig. 1A). Complete results of template selection for homology modeling are provided in Supplementary Table 3. The best structure generated for each target was optimized by ModRefiner server. Refined model of Q5ZV69 had RMSD 0.1444 and TM score 0.9783 to initial model. After refinement, the PDB structure of each protein was evaluated through PROCHECK and ERRAT. Psi-Phi pains in Ramachandran Plot revealed that protein Q5ZV69 had 91.9\% residues in most favored regions, 7.8\% residues in additional allowed region and $0.3 \%$ in generously allowed region (Supplementary Fig. 1B). According to ERRAT, the overall quality factor of this protein was 76.1084 (Supplementary Fig. 2). An ERRAT score of 50 is normally acceptable and the value explains the statistics of non-bonded interaction molecules. This indicates that the modeled structure is reliable and stable.

\section{Antigenic protein selection and T-Cell epitope prediction}

From the top membrane proteins, LEGPH Protein TolB (Accession ID: Q5ZV69) was selected based on protein-protein interaction analysis with total antigenicity score of 0.6740 for vaccine design against Legionella. ProtParam tool was used for analyzing the physicochemical properties of the vaccine proteins. Results of which are shown in Supplementary Table 4. In addition, various immunogenic epitopes from LEGPH Protein TolB were identified to be potential T cell epitopes that can bind to wide variety of different HLA-A and HLA-B cells with greater binding affinity. Epitopes that bind to the maximum number of HLA cells were selected. 
Transmembrane topology, antigenicity, population coverage \& allergenicity assessment of $T$ T-cell epitopes

Best LEGPH Protein TolB epitopes were ranked based on their topology of the transmembrane and antigenicity score (Table 7). All of the indicated alleles were identified as optimal binders of the proposed epitopes and used to assess population coverage (Fig. 4). Based on studies utilizing four separate allergenicity prediction systems, epitopes classified as non-allergenic to humans have been retained in the predicted epitope list (Table 7).

\section{Toxicity and conservancy analysis of T-Cell epitope}

ToxinPred server predicted the relative toxicity of the top epitopes (Table7). Again, putative epitopes generated from LEGPH Protein TolB were found to be highly conserved (up to 100\%) within specific pathogenic strains. Top epitopes were used to design the final vaccine constructs to allow a wide spectrum of immunity (Table 7).

\section{B-Cell epitope identification and cluster analysis}

B-cell epitopes of the selected protein was generated using a total six algorithms (Table 8). For envelope glycoprotein, peptide sequences from 66-77 and 404-417 were identified as potential B cell epitopes that could stimulate preferred immune reaction (Supplementary Fig. 3A). Regions from 206-212 and 277-287 residues were more accessible (Supplementary Figure 3B), while residues from 194-200 and 294-300 amino acids were considered as possible regions of Betaturn (Supplementary Fig. 3C). On the basis of Karplus and Schulz flexibility prediction, the region of 160-166 and 308-314 residues were most flexible (Supplementary Fig. 3D). Amino acids in 5-23 and 243-252 regions were highly antigenic (Supplementary Figure 3E), while residues in the 174-180 and 283-289 regions were mostly hydrophilic (Supplementary Fig. 3F). Before the final constructs were designed, peptides containing overlapping epitopes between both the top T-cells and B-cells were identified (Supplementary Table 5). 


\section{Final vaccine construction}

Both Clusters and singletons (contains single epitope) were used to construct the final vaccine molecules. A total of 3 constructs with residues with 476 (V1), 561 (V2), and 590 (V3) amino acids were designed (Table 9) and used for analysis.

Allergenicity, antigenicity, physicochemical properties and secondary structure analysis of vaccine constructs

Results revealed construct V1's superiority due to greater antigenicity score (0.603) and nonallergenic behavior (Table 9). The final construct of the vaccine was characterized by the physical and chemical properties. Construct V1's molecular weight was $48.34 \mathrm{kDa}$, while theoretical pI was measured at 9.78 which indicated that the protein should have a net negative charge over the $\mathrm{pI}$ and vice versa. The half-life of the vaccine was expected to be more than $10 \mathrm{~h}$ in $E$. coli in vivo. The estimated rate of extinction and an aliphatic index were 41370 and 61.74 respectively. The protein's computed GRAVY value was -0.545 while the index of instability (33.51) classified the protein as stable. Constructed V1 was, on the opposite, characterized by $6.30 \%$ alpha helix, $24.78 \%$ sheet and $68.92 \%$ coil structure (Supplementary Fig. 4).

\section{Vaccine tertiary structure prediction, refinement, validation and disulfide engineering}

2ymuA from the PDB database was detected as the most suitable V1 template and a singledomain 3D model was created through the Raptor X server (Fig. 5A). All 476 residues were modelled by the server, while only $8 \%$ residues were in the disordered region. The 3D model's $\mathrm{P}$ value was $5.30 \mathrm{e}-11$ which ensured better quality modeling of the proposed vaccine. $81.4 \%, 11.8$ $\%$ and $6.8 \%$ residues were respectively in the favored, allowed and outlier regions prior to refinement. However, $88.4 \%$ residues were in the favored region after refining. Ramachandran Plot showed residues of $8.4 \%$ and $3.2 \%$ respectively in the allowed and outlier regions (Fig. 5B). Homology modelling of construct V2 and V3 was also performed as shown in Supplementary Fig. 5. For construct V1, 71 amino acid pairs were found to have the capacity to shape disulfide bond. However, just 3 pairs i.e., based on the chi3 and B-factor values ASN 
202-GLY 226, SER 211-GLY 217 and ASN 309-LEU 317 met disulfide bond forming requirements (Fig. 6).

\section{Protein-protein docking and molecular dynamics simulation}

Docking study revealed that construct V1 bound in the groove of different HLAs with minimal binding energy which was biologically significant. The predicted binding energy for vaccine V1TLR 2 complex was -1232.8 and $-275.55 \mathrm{KJule} / \mathrm{mol}$ by ClusPro and hdoc server respectively. FireDock output refinement of PatchDock server showed the lowest global energy of -15.64 for solution 2. The lowest binding energy was a measure of highest binding affinity between TLR-2 and vaccine construct. The stability of proteins and their mobility at large scale were revealed by normal mode analysis (NMA). Deformabilty of each residue was negligible and represented by hinges in the chain (Fig. 8A). The B-factor value was equivalent to RMS inferred via NMA (Fig. 8B). The eigenvalue found for the complex was 3.5007e-06 (Fig. 8C). The eigenvalue and variance associated to each normal mode were inversely related (Fig. 8D). The covariance matrix indicated the coupling between pairs i.e. correlated (red), anti-correlated (blue) or uncorrelated (white) motions (Fig. 8E). The elastic network model detected the pairs of residues which were connected via springs (Fig. 8F).

\section{Codon adaptation for in silico cloning and expression in E. coli}

The optimized codon adaptation index (CAI) was found 0.95 and GC content of that swquence was $54.01 \%$. This results showed better expression in E. coli K12 The optimized codons were introduced into the vector $\mathrm{pET} 28 \mathrm{a}(+)$ along with the restriction sites HindIII and BamHI. A clone of 6346 base pair was created in which red color indicated the desired sequence of $1434 \mathrm{bp}$ in $\mathrm{pET} 28 \mathrm{a}(+)$ vector sequence (Fig. 9).

\section{Discussion}


Among all the pathogenic agents responsible for pneumonia and respiratory tract infection, Legonella pneumophila is one of the main causative agent showing high levels of resistance against a large number of antibiotics. Though clinical studies of antibiotic treatment against Legionnaires' disease have been reported but the number of such cases are not quite enough [115]. Hence, Hence, treatment recommendations are limited due to lack of evidence [116]. However, Rahimi and Vesalreported that L. pneumophila strains harbored highest levels of resistance againstciprofloxacin, erythromycin, clarithromycin, moxifloxacin andazithromycin [117]. Therefore, the prime goal of this study was to screen out and determine novel drug targets and vaccine candidates for Legionella pneumophila through subtractive genomics and reverese vaccinology approach.

Computational predictions help to identify essential proteins for the survival of the pathogen, non-homologous to host proteins, as well as no involvement in metabolic pathways of host leading to choose the proteins only present and involve in pathogen specific metabolic pathways. Complete reference proteome of L. pneumophila (2,930 proteins) was searched and downloaded from the NCBI protein database. Proteins involved in several common cellular systems emerged as homologous with same functions between human and bacteria in course of evolution [118,119] which were removed in this study based on their identity with human proteins. Essential proteins are most promising for new antibacterial drug targets since most antibiotics are designed to bind essential gene products [120] and can be considered as pathogen-specific drug targets [121]. The study revealed 125 unique essential proteins of $L$. pneumophila which can be considered as suitable drug targets. Localization is an important aspect of any possible drug target as cellular functions of proteins are often localized in specific compartments of cell, hence studying subcellular localization will be helpful to understand disease mechanisms as well as developing new vaccine candidates and drug targets. Although, both membrane and cytoplasmic proteins could serve the purpose as therapeutic targets [122], membrane proteins habe been mostly reported for vaccine candidates [123]. Hence, in this study membrane proteins were used for vaccine construction whereas cytoplasmic proteins were proposed as suitable drug targets. Again, usage of antibiotics has already reduced their efficiency due to gene mutation and thereby rapid emergence of resistant bacteria [124]. [124]. The antibiotic and antimicrobial resistance crises are observed due to the misuse as well as overuse of these drugs, and a scarcity of developing new drugs by the pharmaceutical industry 
[125,126]. Broad-spectrum drugs medicated for a pathogen or group of the pathogen may cause mutational changes as well as enhance the transfer of gene to other pathogens which can show resistance to drugs leading towards the emergence of resistant bacteria. To avoid these crises, selection of novel drug targets and vaccine candidates is a must; therefore shortlisted 32 proteins were further screened through DrugBank5.1.0 database with default parameters.

Antigenicity score for selected 12 novel drug targeted membrane proteins revealed that only 1 protein was non antigenic whereas the rest 11 showed antigenicity score $>0.4$. These 11 proteins can be used to design B cell epiptopes and T cell epitopes (specific for CTL and HTL) in future to lessen the disease caused by Legionella pneumophila. A number of drugs from different categories such as non-nacrotic analgesics, non-steroidal anti-inflammatory drugs, antidepressants as well as vasodilators were withdrawn during 1960-1999 due to various healthrelatedcross-reactivity causing hepatic, cardiovascular, dermatologist and hematologic toxicities as well as carcinogenic effects [127]. For example, bromfenac [128], ebrotidine [129], trovafloxacin [130] were withdrawn from pharmaceutical markets worldwide since they showed hepatotoxic effects. Therefore, specific recognition must be maintained by an ideal drug target to the drug-treated against it, furthermore, this drug target needs to be significantly different from the host proteins. To avoid severe cross-reaction and adverse effects in human, identification of nonhomologous proteins to human 'anti-targets' (also refferend as essential protein) was a crucial step considered in this study. Targeting Human microbiome nonhomology proteins will be suitable since they are neither involved in common pathways of hostpathogen nor homologous to any human 'anti-targets'.Furthermore drug or vaccine designed and administered for these novel targets will be less harmful to other commensal microbial strains dwelling in different body sites of a healthy human. The study revealed that most of the cytoplasmic proteins are involved in cell wall biosynthesis pathways and essential for cell division. However, targeting three proteins i.e. UDP-N-acetylmuramoyl-L-alanyl-D-glutamate-2,6-diaminopimelate ligase, Trigger factor and Probable lipid II flippaseMurJ also influence the interacting proteins can lead to development of novel therapeutics in The predicted single vaccine candidate Q5ZV69 of this study was analyzed to develop a potential and highly immunogenic vaccine candidate against Legionella pneumophila. Using a variety of bioinfomatics tools, various antigenic epitopes were generated which were extensively investigated for immunogenicity, toxicity profile, allergenicity pattern and conservancy analysis 
The PADRE sequence reportedly decreased the polymorphism of HLAs in the different population [131,132]. In previous in vivo research, the linkers improved immunogenicity of the vaccines [133,134]. Therefore, in the present study, both of these critical considerations were taken into account in developing the final vaccine model Moreover, the results of docking analysis revealed the binding affinity of promiscuous epitopes with different HLA alleles. In addition, interaction between construct V1 and TLR-2 were checked to demonstrate the efficacy of used adjuvants. The vaccine-receptor complex showed minimum deformability as well at molecular level.

\section{Conclusion}

By using the subtractive genomics and reverse vaccinology approach, we are trying to develop novel therapeutics against Legionella pneumophila and may help to reduce the rate of mortality as well as morbidity caused by this pathogen. We particularly considered the key that are the must for survival of the pathogen, non-homologous to the human as well as human microbiota and screened out B/T-cell epitopes of outer membrane protein (OMP). The highest scoring OMP's and epitopes will facilitate future wet lab based experiments for the development of drugs and suitable vaccine candidates against intracellular L. pneumophila infection. After intensive analysis, only 3 proteins were identified and proposed as novel therapeutic targets against L. pneumophila. Only outer membrane protein TolB was identified as potential vaccine candidate with a better antigenicity score. However, we also suggest further in vitro and in vivo laboratory trials to validate our prediction.

\section{References}

1. Chien M, Morozova I, Shi S, Sheng H, Chen J, et al. (2004) The genomic sequence of the accidental pathogen Legionella pneumophila. Science 305: 1966-1968.

2. National Research Council (US) Committee on Drinking Water Contaminants. Review of Methods for Assessing Microbial Pathogens; National Academies Press (US):Washington, DC, USA, 1999. 
3. Yu VL, Plouffe JF, Pastoris MC, Stout JE, Schousboe M, Widmer A, Summersgill J, File T, Heath CM, Paterson DL, Chereshsky A. Distribution of Legionella species and serogroups isolated by culture in patients with sporadic community-acquired legionellosis: an international collaborative survey. The Journal of infectious diseases. 2002 Jul 1;186(1):127-8.

4. Kaufmann, A.F.; McDade, J.E.; Patton, C.M.; Bennett, J.V.; Skaliy, P.; Feeley, J.C.; Anderson, D.C.; Potter, M.E.; Newhouse, V.F.; Gregg, M.B.; et al. Pontiac Fever: Isolation of the Etiologic Agent (Legionella pneumophila) and Demonstration of its Mode of Transmission. Am. J. Epidemiol. 1981, 114, 337-347.

5. Neil, K.; Berkelman, R. Increasing incidence of legionellosis in the United States, 19902005: Changing epidemiologic trends. Clin. Infect. Dis. 2008, 47, 591-599.

6. Centers for Disease Control and Prevention (CDC). Legionellosis-United States, 20002009. MMWR Morb. Mortal. Wkly. Rep. 2011, 60, 1083-1086.

7. Choffnes, E.R.; Mack, A. Global Issues inWater, Sanitation, and Health: Workshop Summary; National Academies Press: Washington, DC, USA, 2009.

8. Mraz A, Weir M. Knowledge to Predict Pathogens: Legionella pneumophila Lifecycle Critical Review Part I Uptake into Host Cells. Water. 2018 Jan 31;10(2):132.

9. Zamboni DS, McGrath S, Rabinovitch M, Roy CR (2003) Coxiella burnetii express type IV secretion system proteins that function similarly to components of the Legionella pneumophila Dot/Icm system. Molecular microbiology 49: 965-976.

10. Zusman T, Yerushalmi G, Segal G (2003) Functional similarities between the icm/dot pathogenesis systems of Coxiella burnetii and Legionella pneumophila. Infection and immunity 71: 3714-3723.

11. Nagai H, Kagan JC, Zhu X, Kahn RA, Roy CR (2002) A bacterial guanine nucleotide exchange factor activates ARF on Legionella phagosomes. Science 295: 679-682.

12. Luo Z-Q, Isberg RR (2004) Multiple substrates of the Legionella pneumophila Dot/Icm system identified by interbacterial protein transfer. Proceedings of the National Academy of Sciences of the United States of America 101: 841-846.

13. Chen J, de Felipe KS, Clarke M, Lu H, Anderson OR, et al. (2004) Legionella effectors that promote nonlytic release from protozoa. Science 303: 1358-1361. 
14. Nagai H, Roy CR (2003) Show me the substrates: modulation of host cell function by type IV secretion systems. Cellular microbiology 5: 373-383.

15. Chopra I, Schofield C, Everett M, O'Neill A, Miller K, et al. (2008) Treatment of healthcare-associated infections caused by Gram-negative bacteria: a consensus statement. The Lancet infectious diseases 8: 133-139.

16. Uddin R, Saeed K (2014) Identification and characterization of potential drug targets by subtractive genome analyses of methicillin resistant Staphylococcus aureus. Computational biology and chemistry 48: 55-63.

17. Nielsen K, Bangsborg JM, Høiby N (2000) Susceptibility of Legionella species to five antibiotics and development of resistance by exposure to erythromycin, ciprofloxacin, and rifampicin. Diagnostic microbiology and infectious disease 36: 43-48.

18. De Giglio O, Napoli C, Lovero G, Diella G, Rutigliano S, et al. (2015) Antibiotic susceptibility of Legionella pneumophila strains isolated from hospital water systems in Southern Italy. Environmental research 142: 586-590.

19. Newton HJ, Ang DK, Van Driel IR, Hartland EL. Molecular pathogenesis of infections caused by Legionella pneumophila. Clinical microbiology reviews. 2010 Apr 1;23(2):274-98.

20. Azim KF, Hasan M, Hossain MN, Somana SR, Hoque SF, Bappy MN, Chowdhury AT, Lasker T. Immunoinformatics approaches for designing a novel multi epitope peptide vaccine against human norovirus (Norwalk virus). Infection, Genetics and Evolution. 2019 Jun 21:103936.

21. Hasan M, Azim KF, Begum A, Khan NA, Shammi TS, Imran AS, Chowdhury IM, Urme SR. Vaccinomics strategy for developing a unique multi-epitope monovalent vaccine against Marburg marburgvirus. Infection, Genetics and Evolution. 2019 Jun 1;70:140-57.

22. Elliott SL, Suhrbier A, Miles JJ, Lawrence G, Pye SJ, Le TT, Rosenstengel A, Nguyen T, Allworth A, Burrows SR, Cox J. Phase I trial of a CD8+ T-cell peptide epitope-based vaccine for infectious mononucleosis. Journal of virology. 2008 Feb 1;82(3):1448-57.

23. Hosen MJ, Hasan M, Chakraborty S, Abir RA, Zubaer A, Coucke P. Comprehensive in silico Study of GLUT10: Prediction of Possible Substrate Binding Sites and Interacting Molecules. Current pharmaceutical biotechnology. 2019. 
24. Asif SM, Asad A, Faizan A, Anjali MS, Arvind A, Neelesh K, et al. Dataset of potential targets for Mycobacterium tuberculosis H37Rv through comparative genome analysis. Bioinformation. 2009; 4(6):245-8.

25. Chong CE, Lim BS, Nathan S, Mohamed R. In silico analysis of Burkholderia pseudomallei genome sequence for potential drug targets. In Silico Biol. 2006; 6(4):3416.

26. Dutta A, Singh SK, Ghosh P, Mukherjee R, Mitter S, Bandyopadhyay D. In silico identification of potential therapeutic targets in the human pathogen Helicobacter pylori. In Silico Biol. 2006; 6(1-2):43-7.

27. Sakharkar KR, Sakharkar MK, Chow VT. A novel genomics approach for the identification of drug targets in pathogens, with special reference to Pseudomonas aeruginosa. In Silico Biol. 2004; 4(3):355- 60.

28. Barh D, Kumar A. In silico identification of candidate drug and vaccine targets from various pathways in Neisseria gonorrhoeae. In Silico Biol. 2009; 9(4):225-31.

29. Rathi B, Sarangi AN, Trivedi N. Genome subtraction for novel target definition in Salmonella typhi. Bioinformation. 2009; 4(4):143-50.

30. Barh D, Jain N, Tiwari S, Parida BP, D’Afonseca V, Li L, et al. A novel comparative genomics analysis for common drug and vaccine targets in Corynebacterium pseudotuberculosis and other CMN group of human pathogens. Chem Biol Drug Des. 2011; 78(1):73-84.

31. Poland GA, Ovsyannikova IG, Jacobson RM. Application of pharmacogenomics to vaccines. Pharmacogenomics 2009; 10 (5): 837-52.

32. Flower DR. Bioinformatics for vaccinology. John Wiley \& Sons 2008; $1^{\text {st }}$ edition: 302.

33. Wong SS, Jeevan T, Kercher L, Yoon SW, Petkova AM, Crumpton JC, et al. A single dose of whole inactivated H7N9 influenza vaccine confers protection from severe disease but not infection in ferrets. Vaccine 2014; 32: 4571-7.

34. Xiang Z, He Y. Genome-wide prediction of vaccine targets for human herpes simplex viruses using Vaxign reverse vaccinology. BMC bioinformatics. 2013 Mar;14(4):S2.

35. Meunier M, Guyard-Nicodème M, Hirchaud E, Parra A, Chemaly M, Dory D. Identification of novel vaccine candidates against Campylobacter through reverse vaccinology. Journal of immunology research. 2016;2016. 
36. Mora M, Telford JL. Genome-based approaches to vaccine development. Journal of Molecular Medicine. 2010 Feb 1;88(2):143-7.

37. Barh D, Tiwari S, Jain N, Ali A, Santos AR, Misra AN, Azevedo V, Kumar A. In silico subtractive genomics for target identification in human bacterial pathogens. Drug Development Research. 2011 Mar;72(2):162-77.

38. Paul SM, Mytelka DS, Dunwiddie CT, Persinger CC, Munos BH, et al. (2010) How to improve R\&D productivity: the pharmaceutical industry's grand challenge. Nature reviews Drug discovery 9: 203.

39. Hasan M, Ghosh PP, Azim KF, Mukta S, Abir RA, Nahar J, Khan MM. Reverse vaccinology approach to design a novel multi-epitope subunit vaccine against avian influenza A (H7N9) virus. Microbial pathogenesis. 2019 May 1;130:19-37.

40. Chien, M., et al., The genomic sequence of the accidental pathogen Legionella pneumophila. Science, 2004. 305(5692): p. 1966-1968.

41. Huang, Y., et al., CD-HIT Suite: a web server for clustering and comparing biological sequences. Bioinformatics, 2010. 26(5): p. 680-682.

42. Zerbino, D.R., et al., Ensembl 2018. Nucleic acids research, 2017. 46(D1): p. D754D761.

43. Shanmugham, B. and A. Pan, Identification and characterization of potential therapeutic candidates in emerging human pathogen Mycobacterium abscessus: a novel hierarchical in silico approach. PLoS One, 2013. 8(3): p. e59126.

44. Luo, H., et al., DEG 10, an update of the database of essential genes that includes both protein-coding genes and noncoding genomic elements. Nucleic acids research, 2013. 42(D1): p. D574-D580.

45. Kanehisa, M. and S. Goto, KEGG: kyoto encyclopedia of genes and genomes. Nucleic acids research, 2000. 28(1): p. 27-30.

46. Qiu, Y.-Q., KEGG pathway database. Encyclopedia of Systems Biology, 2013: p. 10681069.

47. Moriya, Y., et al., KAAS: an automatic genome annotation and pathway reconstruction server. Nucleic acids research, 2007.35(suppl_2): p. W182-W185. 
48. Li, Y.H., et al., SVM-Prot 2016: a web-server for machine learning prediction of protein functional families from sequence irrespective of similarity. PLoS One, 2016. 11(8): p. e0155290.

49. Damte, D., et al., Putative drug and vaccine target protein identification using comparative genomic analysis of KEGG annotated metabolic pathways of Mycoplasma hyopneumoniae. Genomics, 2013. 102(1): p. 47-56.

50. Yu, N.Y., et al., PSORTb 3.0: improved protein subcellular localization prediction with refined localization subcategories and predictive capabilities for all prokaryotes. Bioinformatics, 2010. 26(13): p. 1608-1615.

51. Yu, C.S., C.J. Lin, and J.K. Hwang, Predicting subcellular localization of proteins for Gram-negative bacteria by support vector machines based on n-peptide compositions. Protein science, 2004. 13(5): p. 1402-1406.

52. Bhasin, M., A. Garg, and G. Raghava, PSLpred: prediction of subcellular localization of bacterial proteins. Bioinformatics, 2005. 21(10): p. 2522-2524.

53. Wishart, D.S., et al., DrugBank 5.0: a major update to the DrugBank database for 2018. Nucleic acids research, 2017. 46(D1): p. D1074-D1082.

54. Doytchinova, I.A. and D.R. Flower, VaxiJen: a server for prediction of protective antigens, tumour antigens and subunit vaccines. BMC bioinformatics, 2007. 8(1): p. 4.

55. Kinross, J.M., A.W. Darzi, and J.K. Nicholson, Gut microbiome-host interactions in health and disease. Genome medicine, 2011.3(3): p. 14.

56. Reid, G., et al., Microbiota restoration: natural and supplemented recovery of human microbial communities. Nature Reviews Microbiology, 2011. 9(1): p. 27.

57. Schommer, N.N. and R.L. Gallo, Structure and function of the human skin microbiome. Trends in microbiology, 2013. 21(12): p. 660-668.

58. Cogen, A., V. Nizet, and R. Gallo, Skin microbiota: a source of disease or defence? British Journal of Dermatology, 2008. 158(3): p. 442-455.

59. Sears, C.L., A dynamic partnership: celebrating our gut flora. Anaerobe, 2005. 11(5): p. 247-251.

60. Guarner, F. and J.-R. Malagelada, Gut flora in health and disease. The Lancet, 2003. 361(9356): p. 512-519. 
61. Wadood, A., et al., Subtractive genome analysis for in silico identification and characterization of novel drug targets in Streptococcus pneumonia strain JJA. Microbial pathogenesis, 2017.

62. Savage, D.C., Microbial ecology of the gastrointestinal tract. Annual Reviews in Microbiology, 1977. 31(1): p. 107-133.

63. Peterson, J., et al., The NIH human microbiome project. Genome research, 2009. 19(12): p. 2317-2323.

64. Methe, B.A., et al., A framework for human microbiome research. Nature, 2012. 486(7402): p. 215.

65. Szklarczyk, D., et al., The STRING database in 2017: quality-controlled protein-protein association networks, made broadly accessible. Nucleic acids research, 2016: p. gkw937.

66. Kuntal, B.K., P. Aparoy, and P. Reddanna, EasyModeller: A graphical interface to MODELLER. BMC research notes, 2010. 3(1): p. 226.

67. $\mathrm{Xu}, \mathrm{D}$. and $\mathrm{Y}$. Zhang, Improving the physical realism and structural accuracy of protein models by a two-step atomic-level energy minimization. Biophysical journal, 2011. 101(10): p. 2525-2534.

68. Laskowski, R.A., et al., PROCHECK: a program to check the stereochemical quality of protein structures. Journal of applied crystallography, 1993. 26(2): p. 283-291.

69. Colovos, C. and T.O. Yeates, Verification of protein structures: patterns of nonbonded atomic interactions. Protein science, 1993. 2(9): p. 1511-1519.

70. Gasteiger E, Hoogland C, Gattiker A, Duvaud S, Wilkins MR, Appel RD Bairoch. A Protein Identification and Analysis Tools on the ExPASy Server. Nucleic Acids Res. 2003;31:3784-3788.

71. Buus S, Lauemoller S, Worning P, Kesmir C, Frimurer T, Corbet S, et al. Sensitive quantitative predictions of peptide-MHC binding by a 'Query by Committee'artificial neural network approach. HLA. 2003;62:378-84.

72. Krogh A, Larsson B, Von Heijne G, Sonnhammer EL. Predicting transmembrane protein topology with a hidden markov model: application to complete genomes. Journal of molecular biology. 2001;305:567-80.

73. Dimitrov I, Bangov I, Flower DR, Doytchinova1 I. AllerTOP v.2- a server for in silico prediction of allergens. J. of Molecular Modeling. 2013;20:2278. 
74. Dimitrov I, Naneva L, Doytchinova1 I, Bangov I. AllergenFP: allergenicity prediction by descriptor fingerprints. Bioinformatics. 2014;30: 846-851.

75. Chrysostomou C and Seker H. Prediction of protein allergenicity based on signalprocessing bioinformatics approach. $36^{\text {th }}$ annual international conference of the IEEE engineering in medicine and biology society. 2014;2014:808-11.

76. Fiers M WEJ, Kleter GA, Nijland H, Peijnenburg A, Nap JP and Ham R. Allermatch ${ }^{\mathrm{TM}}$, a webtool for the prediction of potential allergenicity according to current FAO/WHO Codex alimentarius guidelines. BMC Bioinformatics. 2004;5:133.

77. Kolaskar A, Tongaonkar PC. A semi-empirical method for prediction of antigenic determinants on protein antigens. FEBS letters. 1990;276:172-4.

78. Karplus P, Schulz G. Prediction of chain flexibility in proteins. Naturwissenschaften. 1985;72:212-3.

79. Chou P, Fasman G. Prediction of the secondary structure of proteins from their amino acid sequence. Adv. Enzymol. 1978;47:45-148.

80. Emini EA, Hughes JV, Perlow D, Boger J. Induction of hepatitis A virus-neutralizing antibody by a virus-specific synthetic peptide. Journal of virology. 1985;55:836-9.

81. Parker J, Guo D and Hodges R. New hydrophilicity scale derived from high-performance liquid chromatography peptide retention data: correlation of predicted surface residues with antigenicity and X-ray-derived accessible sites. Biochemistry. 1986;25:5425-32.

82. Jespersen MC, Peters B, Nielsen M, Marcatili P. BepiPred-2.0: improving sequencebased B-cell epitope prediction using conformational epitopes. Nucleic acids research. 2017;45:W24-W9.

83. Kim Y, Ponomarenko J, Zhu Z, Tamang D, Wang P, Greenbaum J, Lundegaard C, Sette A, Lund O, Bourne PE, Nielsen M. Immune epitope database analysis resource. Nucleic acids research. 2012 May 18;40(W1):W525-30.

84. Rana A, Akhter, YA. multi-subunit based, thermodynamically stable model vaccine using combined immunoinformatics and protein structure based approach. Immunobiology. 2016;221:544-557.

85. Hajighahramani N, Nezafat N, Eslami M, Negahdaripour M, Rahmatabadi SS and Ghasemi Y. Immunoinformatics analysis and in silico designing of a novel multi-epitope peptide vaccine against Staphylococcus aureus. Infect. Genet. Evol. 2017;48:83-94. 
86. Pandey RK, Sundar S, Prajapati VK. Differential expression of miRNA regulates T cell differentiation and plasticity during visceral leishmaniasis infection. Front. Microbiol. 2016;7:206.

87. Hasan M, Hakim A, Iqbal A, Bhuiyan FR, Begum MK, Sharmin S and Abir RA (2015) Computational study and homology modeling of phenol hydroxylase: key enzyme for phenol degradation. Int J ComputBioinfo In Silico Model 4(4):691-698

88. Kosciolek T, Jones DT. De novo structure prediction of globular proteins aided by sequence variation-derived contacts. PloS One. 2014;9(3):e92197.

89. Petersen B, Lundegaard C, Petersen TN. NetTurnP-neural network prediction of betaturns by use of evolutionary information and predicted protein sequence features. PLoS One. 2010;5(11):e15079.

90. Thaysen-Andersen M, Packer NH. Site-specific glycoproteomics confirms that protein structure dictates formation of $\mathrm{N}$-glycan type, core fucosylation and branching. Glycobiology. 2012;22(11):1440-52.

91. Kallberg M, Margaryan G, Wang S, Ma J and Xu J. RaptorX server: a resource for template-based protein structure modeling. InProtein Structure Prediction. 2014;1137:1727.

92. Peng J, Xu J. RaptorX: exploiting structure information for protein alignment by statistical inference. Proteins: Structure, Function, and Bioinformatics. 2011;79(S10):161-71.

93. Xu D and Zhang Y. Improving the Physical Realism and Structural Accuracy of Protein Models by a Two-step Atomic-level Energy Minimization. Biophysical Journal. 2011;101:2525-2534.

94. Zhang J, Liang Y, Zhang Y. Atomic-Level Protein Structure Refinement Using Fragment-Guided Molecular Dynamics Conformation Sampling. Structure 2011;19:1784-1795.

95. Lovell SC, Davis IW, Arendall WB, Bakker PIW, Word JM, Prisant MG, Richardson JS, Richardson DC. Structure validation by Calpha geometry: phi, psi and beta deviation. Proteins: Structure, Function \& Genetics. 2002;50:437-450. 
96. Hasan M, Joy ZF, Bhuiyan EH, Islam MS (2015) In Silico Characterization and Motif Election of Neurotoxins from Snake Venom. American Journal of Biochemistry \& Biotechnology 11(2):84

97. Craig DB, Dombkowski AA. Disulfide by Design 2.0: a web-based tool for disulfide engineering in proteins. BMC Bioinformatics. 2013;14:346.

98. Solanki V, Tiwari V. Subtractive proteomics to identify novel drug targets and reverse vaccinology for the development of chimeric vaccine against Acinetobacter baumannii. Scientific reports. 2018;8(1):9044.

99. Newton HJ, Ang DK, van Driel IR, Hartland EL. Molecular pathogenesis of infections caused by Legionella pneumophila. Clinical microbiology reviews. 2010 Apr $1 ; 23(2): 274-98$.

100. Ahmadishoar S, Kariminik A. Toll-like receptor 2 and its roles in immune responses against Legionella pneumophila. Life sciences. 2017 Nov 1;188:158-62.

101. Comeau SR, Gatchell DW, Vajda S, Camacho CJ. ClusPro: a fully automated algorithm for protein-protein docking. Nucl. Acids Res. 2004; 32: W96-9.

102. Macalino S, Basith S, Clavio N, Chang H, Kang S, Choi S. Evolution of In Silico Strategies for Protein-Protein Interaction Drug Discovery. Molecules 2018; 23(8): 1963.

103. Extra- Kangueane P, Nilofer C. Protein-Protein Docking: Methods and Tools. InProteinProtein and Domain-Domain Interactions. 2018:161-168.

104. Schneidman-Duhovny D, Inbar Y, Nussinov R, Wolfson HJ. PatchDock and SymmDock: servers for rigid and symmetric docking. Nucl. Acids Res. 2005;33:W363-7.

105. Aalten DMF, Groot BL, Findlay JBC, Berendsen HJC, Amadei A. A Comparison of Techniques for Calculating Protein Essential Dynamics. Journal of Computational Chemistry. 1997;18(2):169-181.

106. Wuthrich K, Wagner G, Rene Richarz, and Werner Braun. Correlations between internal mobility and stability of globular proteins, Biophys. J. 1980;549-558.

107. Tama F, Brooks CL. Symmetry, form, and shape: guiding principles for robustness in macromolecular machines. Annu. Rev. Biophys. Biomol. Struct. 2006;35:115-33.

108. Cui Q, Bahar I. normal mode analysis theoretical and applications to biological and chemical systems. Briefing in Bioinformatics. 2007;8(5):378-379. 
109. Lopez-Blanco JR, Garzon JI and Chacon P. iMod: multipurpose normal mode analysis in internal coordinates. Bioinformatics. 2011;27(20):2843-2850.

110. Lopez-Blanco JR, Aliaga JI, Quintana-Orti ES, Chacon P. iMODS: internal coordinates normal mode analysis server. Nucleic Acids Res. 2014;42:W271-W276.

111. Awan FM, Obaid A, Ikram A, Janjua HA. Mutation-structure function relationship based integrated strategy reveals the potential impact of deleterious missense mutations in autophagy related proteins on hepatocellular carcinoma (HCC): a comprehensive informatics approach. Int. J. Mol. Sci. 2017;18(1):139.

112. Prabhakar PK, Srivastava A, Rao KK and Balaji PV. Monomerization alters the dynamics of the lid region in campylobacter jejuniCstII: an MD simulation study. J. Biomol. Struct. Dyn. 2016;34(4):778-79.

113. Grote, A. et al. J Cat: a novel tool to adapt codon usage of a target gene to its potential expression host. Nucleic acids research. 2005; 33:W526-531.

114. Hasan M, Islam S, Chakraborty S, Mustafa AH, Azim KF, Joy ZF, Hossain MN, Hossain $\mathrm{S}$ and Hasan MN. Contriving a chimeric polyvalent vaccine to prevent infections caused by herpes simplex virus (type-1 and type-2): an exploratory immunoinformatic approach. J BiomolStructDyn. 2019. DOI: 10.1080/07391102.2019.1647286

115. Bartram, J., Chartier, Y., Lee, J. V., Pond, K., \&Surman-Lee, S. (Eds.). (2007). Legionella and the prevention of legionellosis. World Health Organization.

116. Yoo BK et al. (2004). Gemifloxacin: a new fluoroquinolone approved for treatment of respiratory infections. Annals of Pharmacotherapy, 38:1226-1235.

117. Rahimi B, Vesal A (2017). Antimicrobial Resistance Properties of Legionella pneumophila Isolated From The Cases of Lower Respiratory Tract Infections. Biomed. Pharma. J.; 10(1), 59-65.

118. Hediger, M.A., E. Turk, and E.M. Wright, Homology of the human intestinal $\mathrm{Na} /$ /glucose and Escherichia coli $\mathrm{Na}+$ /proline cotransporters. Proceedings of the National Academy of Sciences, 1989. 86(15): p. 5748-5752.

119. Swango, K., et al., Amino acid homologies between human biotinidase and bacterial aliphatic amidases: putative identification of the active site of biotinidase. Molecular genetics and metabolism, 2000. 69(2): p. 111-115. 
120. Zhang, R., H.Y. Ou, and C.T. Zhang, DEG: a database of essential genes. Nucleic acids research, 2004. 32(suppl_1): p. D271-D272.

121. Judson, N. and J.J. Mekalanos, TnAraOut, a transposon-based approach to identify and characterize essential bacterial genes. Nature biotechnology, 2000. 18(7): p. 740.

122. Michael, C. A., Dominey-Howes, D. \& Labbate, M. The antimicrobial resistance crisis: causes, consequences, and management. Front. Public Health2, 145 (2014).

123. Baliga, P., Shekar, M. \&Venugopal M. N. Potential Outer Membrane Protein Candidates for Vaccine Development Against the Pathogen Vibrio anguillarum: A Reverse Vaccinology Based Identification. Curr. Microbiol.75, 368-77 (2018).

124. Golkar, Z., O. Bagasra, and D.G. Pace, Bacteriophage therapy: a potential solution for the antibiotic resistance crisis. The Journal of Infection in Developing Countries, 2014. 8(02): p. 129-136.

125. Bartlett, J.G., D.N. Gilbert, and B. Spellberg, Seven ways to preserve the miracle of antibiotics. Clinical Infectious Diseases, 2013. 56(10): p. 1445-1450.

126. Michael, C.A., D. Dominey-Howes, and M. Labbate, The antimicrobial resistance crisis: causes, consequences, and management. Frontiers in public health, 2014. 2: p. 145.

127. Fung, M., et al., Evaluation of the Characteristics of Safety Withdrawal of Prescription Drugs from Worldwide Pharmaceutical Markets-1960 to 1999. Drug Information Journal, 2001. 35(1): p. 293-317.

128. Moses, P.L., et al., Severe hepatotoxicity associated with bromfenac sodium. The American journal of gastroenterology, 1999. 94(5): p. 1393.

129. Andrade, R.J., et al., Acute liver injury associated with the use of ebrotidine, a new H2receptor antagonist. Journal of hepatology, 1999. 31(4): p. 641-646.

130. Lazarczyk D, Goldstein N, Gordon S. (2000) Trovafloxacin hepatotoxicity. The American journal of gastroenterology 95(9):2585.

131. Ghaffari-Nazari, H. et al. (2015). Improving Multi-Epitope Long Peptide Vaccine Potency by Using a Strategy that Enhances CD4+T Helpin BALB/c Mice. PloS one 10:e0142563.

132. In silico epitope prediction and immunogenic analysis for penton base epitope-focused vaccine against hydropericardium syndrome in chicken. 
133. Yang, Y. et al. (2015) In silico design of a DNA-based HIV-1 multi-epitope vaccine for Chinese populations. Human Vaccines \&Immunotherapeutics 11:795-805.

134. Khan M, Khan S, Ali A, Akbar H, Sayaf AM, Khan A, Wei DQ. Immunoinformatics approaches to explore Helicobacter Pylori proteome (Virulence Factors) to design B and T cell multi-epitope subunit vaccine. Scientific reports. 2019 Sep 16;9(1):1-3.

\section{$\underline{\text { Table Captions }}$}

Table 1: Subtractive genomic analysis scheme towards the identification of novel therapeutic targets

Table 2: Proteins involved in pathogen specific pathways

Table 3: Identified druggable targets with drug names

Table 4: List of probable antigenic proteins for vaccine targets

Table 5: Human microflora non-homology analysis and subcellular localization

Table 6: List of identified novel drug targets against Legionella pneumophila

Table7: Predicted T-cell epitopes (MHC-I peptides and MHC-II peptides) of LEGPH protein TolB

Table 8: Allergenicity pattern of the predicted B-cell epitopes generated from LEGPH protein TolB

Table 9: Allergenicity prediction and antigenicity analysis of designed vaccine constructs

Table 10: Docking score of vaccine construct V1 with different HLA alleles including HLADRB1*03:01 (1A6A), (HLA-DRB5*01:01 (1H15), HLA-DRB3*01:01 (2Q6W), HLADRB1*04:01 (2SEB), HLA-DRB1*01:01 (2FSE), and HLA-DRB3*02:02 (3C5J)

\section{Supplementary Tables}

Supplementary Table 1: KO assigned (KEGG orthlogy) proteins not involved in any metabolic pathway.

Supplementary Table 2: Functional family classification of the hypothetical proteins by SVMProt server.

Supplementary Table 3: Templates used for homology modeling by EasyModeller 4.0. 
Supplementary Table 4: ProtParam analysis of LEGPH protein TolB.

Supplementary Table 5: Identified epitope clusters among the top CTL, HTL and BCL epitopes.

\section{Figure captions}

Fig. 1. Proteome exploration of Legionella pneumophila to identify novel drug targets.

Fig. 2. Flow chart summarizing the protocols for the prediction of epitope based vaccine candidate by in silico reverse vaccinology technique.

Fig. 3. Investigation of Protein-Protein Interactions throughSTRING v10.5 server, A: UDP-Nacetylmuramoyl-L-alanyl-D-glutamate--2,6-diaminopimelate ligase (murE), B: Trigger factor (tig), C: Lipid II flippaseMurJ (mviN), D: Potassium transport system protein kup 1 (kup1), E:Protein TolB (tolB).

Fig. 4. Population coverage analysis of LEGPH protein TolB.

Fig. 5. Tertiary structure prediction and validation of vaccine protein V1, A: Cartoon format B: Validation of the 3D structure of vaccine protein V1 by Ramachandran plot analysis.

Fig. 6. Disulfide engineering of vaccine protein V1; A: Initial form, B: Mutant form.

Fig. 7. Docked complex of vaccine construct V1 with human TLR8; A: Cartoon format and B: Ball structure.

Fig. 8. Molecular dynamics simulation of vaccine protein V1-TLR2 complex; stability of the protein-protein complex was investigated through mobility (A), eigenvalue (B), B-factor (C), deformability (D), covariance (E) and elastic network (F) analysis.

Fig. 9. Restriction digestion (A) and in silico cloning (B) of the gene sequence of final vaccine construct V1 into pET28a(+) expression vector. Target sequence was inserted between HindIII (173) and BamHI (198). 


\section{Supplementary Figures}

Supplementary Fig. 1. Tertiary structure prediction of the vaccine target through EasyModeller 4.0 (A) and Ramachandran Plot analysis (B).

Supplementary Fig. 2. Quality factor analysis of modeled 3D structure of LEGPH protein TolB by ERRAT.

Supplementary Fig. 3. Prediction of B cell linear epitope and intrinsic properties for LEGPH protein Tol B using different scales (A: Bepipred, B: Surface accessibility, C:Emini surface, D: Flexibility, E: Antigenicity, F: Hydrophilicity). (For each graph: x-axis and yaxis represent the position and score; residues that fall above the threshold value are shown in yellow color; the highest peak in yellow color identifies most favored position).

Supplementary Fig. 4. Secondary structure prediction of designed vaccine V1 using PESIPRED server

Supplementary Fig. 5. 3D modelled structure of vaccine protein V2 (A) and V3 (B) generated via RaptorX server.

\section{Supplementary Files}

Supplementary File 1: A total 210 'anti-targets' of human

Supplementary File 2: Unique pathways of Legionella pneumophila retrieved from KEGG server.

Supplementary File 3: Subcellular localization of nonhomologous essential proteins involved in unique pathways of Legionella pneumophila 
Supplementary File 4: Details of Protein-Protein Interactions through STRING v10.

Table 1: Subtractive genomic analysis scheme towards the identification of novel therapeutic targets

\begin{tabular}{|c|c|c|}
\hline No. & Steps & $\begin{array}{l}\text { Legionella pneumophila subsp. } \\
\text { pneumophila (strain Philadelphia } \\
\text { / ATCC } 33152 \text { / DSM 7513) }\end{array}$ \\
\hline 1 & Total number of proteins & 2930 \\
\hline 2 & Removed paralogous ( $>60 \%$ identical) in CD-Hit & 2878 \\
\hline 3 & $\begin{array}{l}\text { Number of proteins nonhomologous to } H \text {. sapiens using } \\
\text { BLASTp (E value } 10^{-3} \text { ) }\end{array}$ & 2010 \\
\hline 4 & $\begin{array}{l}\text { Essential proteins in DEG } 15.2 \text { server (E value } \leq 10^{-100} \text {, Bit } \\
\text { score }>100)\end{array}$ & 125 \\
\hline 5 & $\begin{array}{l}\text { Essential Proteins involved only in unique metabolic } \\
\text { pathways (KAAS at KEGG) }\end{array}$ & 4 \\
\hline 6 & $\begin{array}{l}\text { Proteins assigned KO (KEGG Orthology) but not assigned } \\
\text { in any pathway }\end{array}$ & 29 \\
\hline 7 & $\begin{array}{l}\text { Hypothetical essential proteins assigned KO (KEGG } \\
\text { Orthology) but not assigned in any pathway }\end{array}$ & 3 \\
\hline
\end{tabular}




\begin{tabular}{|c|c|c|}
\hline 8 & $\begin{array}{l}\text { Essential membrane proteins using PSORTb, CELLO, } \\
\text { ngLOC, PSLpred servers }\end{array}$ & 12 \\
\hline 9 & $\begin{array}{l}\text { Essential cytoplasmic proteins using PSORTb, CELLO, } \\
\text { ngLOC, PSLpred servers }\end{array}$ & 13 \\
\hline & Proteins of unknown location & 1 \\
\hline 10 & $\begin{array}{l}\text { Essential proteins found to be novel in DrugBank 5.1.0 } \\
\text { (using default parameters) }\end{array}$ & 25 \\
\hline 11 & $\begin{array}{l}\text { Proteins non-homologous to 'anti-targets' using BLASTp } \\
\text { (E value }<0.005 \text {, Identity }<30 \% \text {, Query length }>30 \% \text { ) }\end{array}$ & 25 \\
\hline 12 & $\begin{array}{l}\text { Membrane proteins showing antigenicity using VexiJen } \\
\text { v2.0 (Threshold value }>0.4 \text { ) }\end{array}$ & 12 \\
\hline 13 & $\begin{array}{l}\text { Number of cytoplasmic and membrane proteins less similar } \\
\text { to Human microbiota using BLASTp against } \\
\text { "43021[BioProject]" } \quad \text { (E value 1, Identity<47\%) }\end{array}$ & 5 \\
\hline 14 & Proteins selected for epitope design & 1 \\
\hline 15 & Novel drug targets & 3 \\
\hline
\end{tabular}


Table 2:Proteins involved in pathogen specific pathways

\begin{tabular}{|l|l|l|l|l|}
\hline S. no. & $\begin{array}{l}\text { KO } \\
\text { assignment }\end{array}$ & $\begin{array}{l}\text { Accession } \\
\text { no. }\end{array}$ & Protein name & Pathway name \\
\hline 1 & K18138 & $\operatorname{tr|Q5ZXL1~}$ & Multidrug resistance protein & $\begin{array}{l}\text { beta-Lactam resistance; Cationic } \\
\text { antimicrobial peptide (CAMP) } \\
\text { resistance }\end{array}$ \\
\hline 2 & K01928 & $\operatorname{tr} \mid$ Q5ZX16 & $\begin{array}{l}\text { alanyl-D-glutamate--2,6- } \\
\text { diaminopimelate ligase }\end{array}$ & $\begin{array}{l}\text { Lysine biosynthesis; Peptidoglycan } \\
\text { biosynthesis }\end{array}$ \\
\hline 3 & $K 03587$ & $\operatorname{tr} \mid$ Q5ZX17 & $\begin{array}{l}\text { Peptidoglycan } \\
\text { transpeptidaseFtsI }\end{array}$ & $\begin{array}{l}\text { D,D- } \\
\text { Lactam resistance }\end{array}$ \\
\hline 4 & $K 05515$ & $\operatorname{tr|Q5ZVR5}$ & $\begin{array}{l}\text { Peptidoglycan } \\
\text { transpeptidaseMrdA }\end{array}$ & D,D- \\
\hline
\end{tabular}


Table 3: Identified druggable targets with drug names

\begin{tabular}{|c|c|c|c|c|c|c|}
\hline $\begin{array}{l}\text { Sl. } \\
\text { No }\end{array}$ & $\begin{array}{l}\text { Accession } \\
\text { No. }\end{array}$ & Protein name & $\begin{array}{l}\text { Drugbank } \\
\text { Id }\end{array}$ & Drug name & Bit score & $\begin{array}{l}\text { Query } \\
\text { length }\end{array}$ \\
\hline 1 & $\operatorname{tr|Q5ZS52}$ & $\begin{array}{l}\text { RNA polymerase } \\
\text { sigma factor } \mathrm{RpoH}\end{array}$ & DB08874 & $\underline{\text { Fidaxomicin }}$ & 103.605 & 318 \\
\hline 2 & $\operatorname{tr|Q5ZT04~}$ & $\begin{array}{l}\text { RNA polymerase } \\
\text { sigma factor RpoD }\end{array}$ & $\begin{array}{l}\text { DB08226, } \\
\text { DB08266 }\end{array}$ & $\begin{array}{l}\text { Myxopyronin B, } \\
\text { Methyl [(1E,5R)-5-\{3-[(2E,4E)- } \\
\text { 2,5-dimethyl-2,4-octadienoyl]- } \\
\underline{\text { 2,4-dioxo-3,4-dihydro-2H- }} \\
\text { pyran-6- } \\
\text { yl\}hexylidene]carbamate }\end{array}$ & 302.368 & 248 \\
\hline 3 & $\operatorname{tr|Q5ZUP0~}$ & $\begin{array}{l}\text { UDP-N- } \\
\text { acetylmuramate--L- } \\
\text { alanyl-gamma-D- } \\
\text { glutamyl-meso-2,6- } \\
\text { diaminoheptandioate } \\
\text { ligase }\end{array}$ & $\begin{array}{l}\text { DB01673, } \\
\text { DB03909, } \\
\text { DB04395 }\end{array}$ & $\begin{array}{l}\text { Uridine-5'-Diphosphate-N- } \\
\text { Acetylmuramoyl-L-Alanine, } \\
\text { Adenosine-5'-[Beta, Gamma- } \\
\underline{\text { Methylene]Triphosphate, }} \\
\underline{\text { Phosphoaminophosphonic }} \\
\underline{\text { Acid-Adenylate Ester }}\end{array}$ & 145.591 & 398 \\
\hline
\end{tabular}


bioRxiv preprint doi: https://doi.org/10.1101/2020.02.03.922864; this version posted April 25, 2020. The copyright holder for this preprint (which was not certified by peer review) is the author/funder, who has granted bioRxiv a license to display the preprint in perpetuity. It is made available under aCC-BY-NC-ND 4.0 International license.

\begin{tabular}{|c|c|c|c|c|c|c|}
\hline 4 & $\operatorname{tr} \mid \mathrm{Q} 5 Z X L 1$ & $\begin{array}{l}\text { Multidrug resistance } \\
\text { protein }\end{array}$ & $\begin{array}{l}\text { DB03825, } \\
\text { DB04209, } \\
\text { DB03619 }\end{array}$ & $\begin{array}{l}\text { Rhodamine 6G, } \\
\text { Dequalinium, } \\
\text { Deoxycholic Acid }\end{array}$ & 427.557 & 1020 \\
\hline 5 & $\operatorname{tr} \mid \mathrm{Q} 5 Z X 17$ & $\begin{array}{l}\text { Peptidoglycan D,D- } \\
\text { transpeptidaseFtsI }\end{array}$ & $\begin{array}{l}\text { DB00303, } \\
\text { DB00671 }\end{array}$ & $\begin{array}{l}\text { Ertapenem, } \\
\text { Cefixime }\end{array}$ & 122.094 & 632 \\
\hline 6 & $\operatorname{tr|Q5ZVR5~}$ & $\begin{array}{l}\text { Peptidoglycan D,D- } \\
\text { transpeptidaseMrdA }\end{array}$ & $\begin{array}{l}\text { DB01598, } \\
\text { DB01329, } \\
\text { DB01327, } \\
\text { DB01163, } \\
\text { DB01328, } \\
\text { DB01413, } \\
\text { DB01415, } \\
\text { DB00948, } \\
\text { DB00438, } \\
\text { DB00303, } \\
\text { DB06211 }\end{array}$ & $\begin{array}{l}\text { Imipenem, } \\
\text { Cefoperazone, } \\
\text { Cefazolin, } \\
\text { Amdinocillin, } \\
\text { Cefonicid, } \\
\text { Cefepime, } \\
\underline{\text { Ceftibuten, }} \\
\underline{\text { Mezlocillin, }} \\
\underline{\text { Ceftazidime, }} \\
\underline{\text { Ertapenem, }} \\
\underline{\text { Doripenem }}\end{array}$ & 486.493 & 612 \\
\hline 7 & tr|Q5ZZI4 & $\begin{array}{l}\text { Amino acid } \\
\text { permease }\end{array}$ & $\begin{array}{l}\text { DB00123, } \\
\text { DB00125, } \\
\text { DB00129 }\end{array}$ & $\begin{array}{l}\text { L-Lysine, } \\
\text { L-Arginine, } \\
\text { Ornithine }\end{array}$ & 155.606 & 424 \\
\hline
\end{tabular}


Table 4: List of probable antigenic proteins for vaccine targets

\begin{tabular}{|l|l|l|l|}
\hline S. no. & Accession no. & Vaxijen v2.0 score & Subcellular localization \\
\hline 1 & tr|Q5ZS84 & 0.4733 & Inner Membrane \\
\hline 2 & tr|Q5ZUM7 & 0.4869 & Inner Membrane \\
\hline 3 & tr|Q5ZT44 & 0.5906 & Inner Membrane \\
\hline 4 & tr|Q5ZVR6 & 0.6058 & Inner Membrane \\
\hline 5 & sp|Q5ZV69 & 0.6714 & Outer membrane \\
\hline 6 & sp|Q5ZW98 & 0.6393 & Inner Membrane \\
\hline 7 & sp|Q5ZSY2 & 0.4632 & Inner Membrane \\
\hline 8 & sp|Q5ZTN5 & 0.5461 & Inner Membrane \\
\hline 9 & sp|Q5ZRL2 & 0.4190 & Inner Membrane \\
\hline 10 & tr|Q5ZY66 & 0.4935 & Outer membrane \\
\hline 11 & tr|Q5ZX71 & 0.5807 & Inner Membrane \\
\hline
\end{tabular}


Table 5: Human microflora non-homology analysis and subcellular localization

\begin{tabular}{|l|l|l|l}
\hline S. no. & Accession no. & Microbiome similarity & Subcellular localization \\
\hline 1 & $\operatorname{tr|Q5ZX16~}$ & $<46$ & Cytoplasmic \\
\hline 2 & sp|Q5ZUD8 & $<45$ & Cytoplasmic \\
\hline 3 & tr|Q5ZS84 & $<47$ & Inner Membrane \\
\hline 4 & sp|Q5ZV69 & $<47$ & Outer membrane \\
\hline $\mathbf{5}$ & $\mathbf{s p | Q 5 Z W 9 8 ~}$ & $<44$ & Inner Membrane \\
\hline
\end{tabular}

Table 6: List of identified novel drug targets against Legionella pneumophila

\begin{tabular}{|l|l|l|}
\hline S. no. & Accession no. & Protein names \\
\hline 1 & $\operatorname{tr|Q5ZX16~}$ & $\begin{array}{l}\text { UDP-N-acetylmuramoyl-L-alanyl-D-glutamate--2,6-diaminopimelate } \\
\text { ligase }\end{array}$ \\
\hline 2 & sp|Q5ZUD8 & Trigger factor \\
\hline 3 & tr|Q5ZS84 & Probable lipid II flippaseMurJ \\
\hline
\end{tabular}


Table 7: Predicted T-cell epitopes (MHC-I peptides and MHC-II peptides) of LEGPH protein TolB

\begin{tabular}{|c|c|c|c|c|c|c|}
\hline \multicolumn{2}{|r|}{ Epitope } & Length & $\begin{array}{l}\text { Antigenicity } \\
\text { score }\end{array}$ & $\begin{array}{c}\text { Conservan } \\
\text { cy }\end{array}$ & Toxicity & Allergenicity \\
\hline \multirow{10}{*}{ 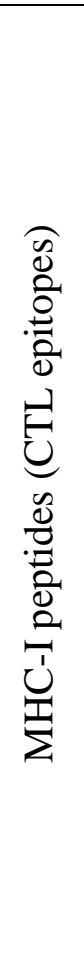 } & IISLFLLLF & 9 & 2.8937 & $88.89 \%$ & $\begin{array}{l}\text { Non-Toxin } \\
(-0.82)\end{array}$ & Non-allergen \\
\hline & TSGRGGSPQ & 9 & 2.5779 & $100 \%$ & $\begin{array}{l}\text { Non-Toxin } \\
(-0.86)\end{array}$ & Non-allergen \\
\hline & TSGRGGSPQV & 10 & 2.5666 & $100 \%$ & $\begin{array}{l}\text { Non-Toxin } \\
(-0.90)\end{array}$ & Non-allergen \\
\hline & SGRGGSPQV & 9 & 2.4721 & $100 \%$ & $\begin{array}{l}\text { Non-Toxin } \\
(-0.83)\end{array}$ & Non-allergen \\
\hline & IGVQNTGGG & 9 & 2.2694 & $83.33 \%$ & $\begin{array}{l}\text { Non-Toxin } \\
\quad(-0.77)\end{array}$ & Non-allergen \\
\hline & RIISLFLLLF & 10 & 2.2479 & $88.89 \%$ & $\begin{array}{l}\text { Non-Toxin } \\
(-0.91)\end{array}$ & Non-allergen \\
\hline & VIALDLELT & 9 & 2.0381 & $100 \%$ & $\begin{array}{c}\text { Non-Toxin } \\
(-1.30)\end{array}$ & Non-allergen \\
\hline & ISLFLLLFT & 9 & 2.0361 & $88.89 \%$ & $\begin{array}{l}\text { Non-Toxin } \\
(-0.99)\end{array}$ & Non-allergen \\
\hline & SGRGGSPQVY & 10 & 2.0168 & $100 \%$ & $\begin{array}{l}\text { Non-Toxin } \\
(-1.04)\end{array}$ & Non-allergen \\
\hline & IISLFLLLFT & 10 & 2.0107 & $88.89 \%$ & $\begin{array}{l}\text { Non-Toxin } \\
\quad(-0.82)\end{array}$ & Non-allergen \\
\hline \multirow{7}{*}{ 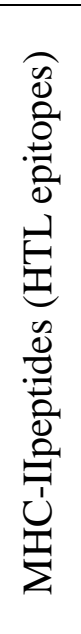 } & $\begin{array}{c}\text { TSGRGGSPQVYR } \\
\text { LSL }\end{array}$ & 15 & 1.8097 & $100 \%$ & $\begin{array}{l}\text { Non-Toxin } \\
(-1.42)\end{array}$ & Non-allergen \\
\hline & $\begin{array}{c}\text { GGRSRYSLEVAD } \\
\text { ADG }\end{array}$ & 15 & 1.6123 & $100 \%$ & $\begin{array}{l}\text { Non-Toxin } \\
(-0.57)\end{array}$ & Non-allergen \\
\hline & $\begin{array}{c}\text { SGRGGSPQVYRL } \\
\text { SLA }\end{array}$ & 15 & 1.5498 & $100 \%$ & $\begin{array}{c}\text { Non-Toxin } \\
(-1.46)\end{array}$ & Non-allergen \\
\hline & $\begin{array}{c}\text { TFGNSIDTEPRYS } \\
\text { PD }\end{array}$ & 15 & 1.4660 & $100 \%$ & $\begin{array}{c}\text { Non-Toxin } \\
(-1.13)\end{array}$ & Non-allergen \\
\hline & $\begin{array}{c}\text { AREGDVQEPAWS } \\
\text { PYL }\end{array}$ & 15 & 1.4197 & $88.89 \%$ & $\begin{array}{l}\text { Non-Toxin } \\
\quad(-0.76)\end{array}$ & Allergen \\
\hline & $\begin{array}{c}\text { YSLEVADADGHN } \\
\text { PQS }\end{array}$ & 15 & 1.3878 & $100 \%$ & $\begin{array}{c}\text { Non-Toxin } \\
(-0.65)\end{array}$ & Non-allergen \\
\hline & QLTFGNSIDTEPR & 15 & 1.3645 & $100 \%$ & Non-Toxin & Allergen \\
\hline
\end{tabular}




\begin{tabular}{|c|c|c|c|c|c|c|}
\hline & YS & & & $(-1.45)$ & \\
\cline { 2 - 6 } & $\begin{array}{c}\text { PKIYDVDLSSGSM } \\
\text { KQ }\end{array}$ & 15 & 1.3508 & $72.22 \%$ & $\begin{array}{c}\text { Non-Toxin } \\
(-0.67)\end{array}$ & Non-allergen \\
\cline { 2 - 6 } & $\begin{array}{c}\text { LTFGNSIDTEPRY } \\
\text { SP }\end{array}$ & 15 & 1.3006 & $100 \%$ & $\begin{array}{c}\text { Non-Toxin } \\
(-1.19)\end{array}$ & Non-allergen \\
\cline { 2 - 6 } & $\begin{array}{c}\text { YDVLSSGMKQ } \\
\text { LTF }\end{array}$ & 15 & 1.2975 & $72.22 \%$ & $\begin{array}{c}\text { Non-Toxin } \\
(-0.77)\end{array}$ & Non-allergen \\
\hline
\end{tabular}

Table 8: Allergenicity pattern of the predicted B-cell epitopes generated from LEGPH protein TolB

\begin{tabular}{|c|c|c|c|c|c|c|}
\hline Protein & method & Start & End & Peptide & $\begin{array}{c}\text { Lengt } \\
\mathrm{h}\end{array}$ & $\begin{array}{c}\text { Allergenic } \\
\text { ity }\end{array}$ \\
\hline \multirow{11}{*}{$\begin{array}{c}\text { LEGPH } \\
\text { Protein TolB }\end{array}$} & \multirow{2}{*}{$\begin{array}{l}\text { Bepipred linear } \\
\text { epitope prediction }\end{array}$} & 66 & 77 & SGPQGANSQSSV & 12 & $\begin{array}{l}\text { Non } \\
\text { Allergen }\end{array}$ \\
\hline & & 404 & 417 & $\begin{array}{c}\text { AREGDVQEPAWS } \\
\text { PY }\end{array}$ & 14 & Allergen \\
\hline & \multirow{2}{*}{$\begin{array}{l}\text { Chou \& Fasman } \\
\text { beta turn prediction }\end{array}$} & 194 & 200 & SWSPNGK & 7 & $\begin{array}{c}\text { Non } \\
\text { Allergen }\end{array}$ \\
\hline & & 294 & 300 & SGRGGSP & 7 & $\begin{array}{c}\text { Non } \\
\text { Allergen }\end{array}$ \\
\hline & \multirow{2}{*}{$\begin{array}{c}\text { Emini surface } \\
\text { accessibility } \\
\text { prediction }\end{array}$} & 206 & 212 & SFEKKKA & 7 & $\begin{array}{c}\text { Non } \\
\text { Allergen }\end{array}$ \\
\hline & & 277 & 287 & IDTEPRYSPDG & 11 & $\begin{array}{c}\text { Non } \\
\text { Allergen }\end{array}$ \\
\hline & \multirow{2}{*}{$\begin{array}{c}\text { Karplus \& Schulz } \\
\text { flexibility } \\
\text { prediction }\end{array}$} & 160 & 166 & QRNGGRS & 7 & Allergen \\
\hline & & 308 & 314 & ADGQISR & 7 & $\begin{array}{l}\text { Non } \\
\text { Allergen }\end{array}$ \\
\hline & \multirow{2}{*}{$\begin{array}{c}\text { Kolaskar \& } \\
\text { Tongaonkar } \\
\text { antigenicity scale }\end{array}$} & 5 & 23 & $\begin{array}{c}\text { IISLFLLLFTGQVIA } \\
\text { LDLE }\end{array}$ & 19 & $\begin{array}{c}\text { Non } \\
\text { Allergen }\end{array}$ \\
\hline & & 243 & 252 & GQHLAVVLSK & 10 & $\begin{array}{c}\text { Non } \\
\text { Allergen }\end{array}$ \\
\hline & Parker & 174 & 180 & DADGHNP & 7 & Allergen \\
\hline
\end{tabular}




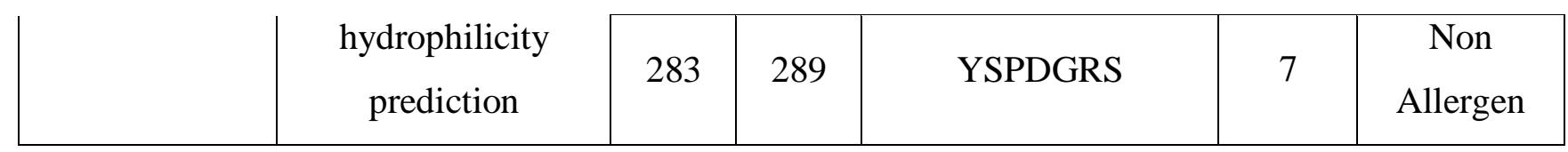

Table 9: Allergenicity prediction and antigenicity analysis of designed vaccine constructs

\begin{tabular}{|c|c|c|c|c|}
\hline $\begin{array}{c}\text { Vaccin } \\
\text { e } \\
\text { Constr } \\
\text { ucts }\end{array}$ & Composition & Complete Sequence of Vaccine Construct & $\begin{array}{c}\text { Allergeni } \\
\text { city }\end{array}$ & $\begin{array}{c}\text { VaxiJen } \\
\text { score } \\
\text { (Threshol } \\
\text { d 0.4) }\end{array}$ \\
\hline V1 & $\begin{array}{l}\text { Predicted } \\
\text { CTL, HTL \& } \\
\text { BCL epitopes } \\
\text { of LEGPH } \\
\text { Protein } \\
\text { TolBwith } \beta \\
\text { defensin } \\
\text { adjuvant } \\
\text { \&PADRE } \\
\text { sequence }\end{array}$ & $\begin{array}{l}\text { EAAAKGIINTLQKYYCRVRGGRCAVLSCLPKE } \\
\text { EQIGKCSTRGRKCCRRKKEAAAKAKFVAAWT } \\
\text { LKAAAGGGSRIISLFLLLFTGGGSTSGRGGSPQ } \\
\text { VYGGGSQVIALDLELTQGGGSIGVQNTGGGP } \\
\text { GGGSLPAREGDVQGGGSDVDLSSGSMKGGGS } \\
\text { TFGNSIDTEGPGPGTPKIYDVDLSSGSMKQLTF } \\
\text { GGPGPGLTFGNSIDTEPRYSPDGGPGPGFTSGR } \\
\text { GGSPQVYRLSLAGPGPGYSLEVADADGHNPQ } \\
\text { SGPGPGRVTFEGNYNARASYTGPGPGGGRSR } \\
\text { YSLEVADADGGPGPGISGPQGANSQSSVSTGP } \\
\text { GPGVIALDLELTQGINSAKKSGPQGANSQSSV } \\
\text { KKAREGDVQEPAWSPYKKSWSPNGKKKSGR } \\
\text { GGSPKKSFEKKKAKKIDTEPRYSPDGKKADGQ } \\
\text { ISRKKIISLFLLLFTGQVIALDLEKKGQHLAVVL } \\
\text { SKKKYSPDGRSKKAKFVAAWTLKAAAGGGS }\end{array}$ & $\begin{array}{l}\text { Non } \\
\text { Allergen }\end{array}$ & 0.6034 \\
\hline $\mathrm{V} 2$ & $\begin{array}{l}\text { Predicted } \\
\text { CTL, HTL \& } \\
\text { BCL epitopes } \\
\text { of LEGPH }\end{array}$ & $\begin{array}{l}\text { EAAAKMAKLSTDELLDAFKEMTLLELSDFVK } \\
\text { KFEETFEVTAAAPVAVAAAGAAPAGAAVEAA } \\
\text { EEQSEFDVILEAAGDKKIGVIKVVREIVSGLGL } \\
\text { KEAKDLVDGAPKPLLEKVAKEAADEAKAKLE } \\
\text { AAGATVTVKEAAAKAKFVAAWTLKAAAGGG } \\
\text { SRIISLFLLLFTGGGSTSGRGGSPQVYGGGSQVI }\end{array}$ & Non & 0.5524 \\
\hline
\end{tabular}




\begin{tabular}{|c|c|c|c|c|}
\hline & $\begin{array}{l}\text { Protein } \\
\text { TolBwith } \\
\text { L7/L12 } \\
\text { ribosomal } \\
\text { protein } \\
\text { adjuvant \& } \\
\text { PADRE } \\
\text { sequence }\end{array}$ & $\begin{array}{l}\text { ALDLELTQGGGSIGVQNTGGGPGGGSLPAREG } \\
\text { DVQGGGSDVDLSSGSMKGGGSTFGNSIDTEG } \\
\text { PGPGTPKIYDVDLSSGSMKQLTFGGPGPGLTF } \\
\text { GNSIDTEPRYSPDGGPGPGFTSGRGGSPQVYRL } \\
\text { SLAGPGPGYSLEVADADGHNPQSGPGPGRVT } \\
\text { FEGNYNARASYTGPGPGGGRSRYSLEVADAD } \\
\text { GGPGPGISGPQGANSQSSVSTGPGPGVIALDLE } \\
\text { LTQGINSAKKSGPQGANSQSSVKKAREGDVQE } \\
\text { PAWSPYKKSWSPNGKKKSGRGGSPKKSFEKK } \\
\text { KAKKIDTEPRYSPDGKKADGQISRKKIISLFLL } \\
\text { LFTGQVIALDLEKKGQHLAVVLSKKKYSPDGR } \\
\text { SKKAKFVAAWTLKAAAGGGS }\end{array}$ & Allergen & \\
\hline V3 & $\begin{array}{l}\text { Predicted } \\
\text { CTL, HTL \& } \\
\text { BCL epitopes } \\
\text { of LEGPH } \\
\text { Protein } \\
\text { TolBwith } \\
\text { HABA } \\
\text { adjuvant \& } \\
\text { PADRE } \\
\text { sequence }\end{array}$ & $\begin{array}{l}\text { EAAAKMAENPNIDDLPAPLLAALGAADLALAT } \\
\text { VNDLIANLRERAEETRAETRTRVEERRARLTKF } \\
\text { QEDLPEQFIELRDKFTTEELRKAAEGYLEAATN } \\
\text { RYNELVERGEAALQRLRSQTAFEDASARAEGY } \\
\text { VDQAVELTQEALGTVASQTRAVGERAAKLVGI } \\
\text { ELEAAAKAKFVAAWTLKAAAGGGSRIISLFLL } \\
\text { LFTGGGSTSGRGGSPQVYGGGSQVIALDLELT } \\
\text { QGGGSIGVQNTGGGPGGGSLPAREGDVQGGG } \\
\text { SDVDLSSGSMKGGGSTFGNSIDTEGPGPGTPKI } \\
\text { YDVDLSSGSMKQLTFGGPGPGLTFGNSIDTEP } \\
\text { RYSPDGGPGPGFTSGRGGSPQVYRLSLAGPGP } \\
\text { GYSLEVADADGHNPQSGPGPGRVTFEGNYNA } \\
\text { RASYTGPGPGGGRSRYSLEVADADGGPGPGIS } \\
\text { GPQGANSQSSVSTGPGPGVIALDLELTQGINSA } \\
\text { KKSGPQGANSQSSVKKAREGDVQEPAWSPYK } \\
\text { KSWSPNGKKKSGRGGSPKKSFEKKKAKKIDT } \\
\text { EPRYSPDGKKADGQISRKKIISLFLLLFTGQVIA } \\
\text { LDLEKKGQHLAVVLSKKKYSPDGRSKKAKFV } \\
\text { AAWTLKAAAGGGS }\end{array}$ & $\begin{array}{c}\text { Non } \\
\text { Allergen }\end{array}$ & 0.5726 \\
\hline
\end{tabular}


Table 10: Docking score of vaccine construct V1 with different HLA alleles including HLADRB1*03:01 (1A6A), (HLA-DRB5*01:01 (1H15), HLA-DRB3*01:01 (2Q6W), HLADRB1*04:01 (2SEB), HLA-DRB1*01:01 (2FSE), and HLA-DRB3*02:02 (3C5J)

\begin{tabular}{|c|c|c|c|c|c|c|}
\hline $\begin{array}{c}\text { Vaccine } \\
\text { Construct }\end{array}$ & $\begin{array}{c}\text { PDB ID of the } \\
\text { HLA Alleles }\end{array}$ & $\begin{array}{c}\text { Global } \\
\text { Energy }\end{array}$ & $\begin{array}{c}\text { Hydrogen } \\
\text { Bond Energy }\end{array}$ & ACE & Score & Area \\
\hline \multirow{4}{*}{} & 1A6A & -12.98 & -4.93 & 7.18 & 17648 & 3028.30 \\
\cline { 2 - 7 } & 1H15 & -30.47 & -5.55 & 5.82 & 16608 & 2414.80 \\
\cline { 2 - 7 } & 2Q6W & -10.99 & -2.58 & 7.65 & 17294 & 2662.20 \\
\cline { 2 - 7 } V1 & 2SEB & -27.99 & -8.91 & 0.83 & 18036 & 2334.50 \\
\cline { 2 - 7 } & 2FSE & -1.43 & -0.46 & 0.05 & 19568 & 2748.70 \\
\cline { 2 - 7 } & 3C5J & -9.43 & -3.63 & 15.90 & 16902 & 2337.90 \\
\hline
\end{tabular}

Supplementary Table 1:KO assigned (KEGG orthlogy) proteins not involved in any metabolic pathway

\begin{tabular}{|l|l|l|l|}
\hline S. no. & KO assignment & Accession no. & Protein name \\
\hline 1 & K03797 & tr|Q5ZY73 & Carboxy-terminal protease \\
\hline 2 & K03294 & tr|Q5ZZI4 & Amino acid permease \\
\hline 3 & K09822 & sp|Q5ZYZ0 & Hypothetical protein \\
\hline 4 & K07568 & sp|Q5ZU04 & S-adenosylmethionine:tRNAribosyltransferase-isomerase \\
\hline 5 & K06941 & sp|Q5ZV93 & Dual-specificity RNA methyltransferaseRlmN \\
\hline
\end{tabular}




\begin{tabular}{|c|c|c|c|}
\hline 6 & K03980 & $\operatorname{tr} \mid \mathrm{Q} 5 Z \mathrm{ZS} 84$ & Probable lipid II flippaseMurJ \\
\hline 7 & K03466 & $\operatorname{tr|Q5ZUM7}$ & Cell division protein FtsK \\
\hline 8 & K03089 & $\operatorname{tr} \mid \mathrm{Q} 5 Z \mathrm{ZS} 52$ & RNA polymerase sigma factor RpoH \\
\hline 9 & K07007 & $\operatorname{tr|Q5ZS92}$ & Hypothetical protein \\
\hline 10 & K03656 & $\operatorname{tr|Q5ZRR4~}$ & ATP-dependent DNA helicase Rep \\
\hline 11 & K03837 & $\operatorname{tr|Q5ZT44~}$ & Serine transporter \\
\hline 12 & K03086 & $\operatorname{tr|Q5ZT04~}$ & LEGPH RNA polymerase sigma factor RpoD \\
\hline 13 & K03609 & $\operatorname{tr|Q5ZUR8~}$ & Site-determining protein \\
\hline 14 & K02600 & $\operatorname{tr|Q5ZRV3~}$ & Transcription termination/antitermination protein NusA \\
\hline 15 & K03722 & $\operatorname{tr|Q5ZU85}$ & ATP dependent DNA helicase \\
\hline 16 & K03592 & $\operatorname{tr} \mid \mathrm{Q} 5 \mathrm{ZUM} 2$ & Peptide maturation protein PmbA \\
\hline 17 & K19810 & $\operatorname{tr|Q5ZYS3}$ & L-lysine 2,3-aminomutase, radical SAM domain protein \\
\hline 18 & K05837 & $\operatorname{tr|Q5ZVR6~}$ & Peptidoglycan glycosyltransferaseMrdB \\
\hline 19 & K03641 & sp|Q5ZV69 & Protein TolB \\
\hline 20 & K03545 & sp|Q5ZUD8 & Trigger factor \\
\hline 21 & K03549 & sp|Q5ZW98 & Probable potassium transport system protein kup 1 \\
\hline 22 & K03549 & sp|Q5ZSY2 & Probable potassium transport system protein kup \\
\hline 23 & K03549 & sp|Q5ZTN5 & $\begin{array}{l}\text { LEGPH Probable potassium transport system protein kup } \\
2\end{array}$ \\
\hline 24 & K13292 & sp|Q5ZRL2 & Prolipoproteindiacylglyceryltransferase \\
\hline 25 & K06915 & $\operatorname{tr|Q5ZYU2~}$ & Hypothetical protein \\
\hline
\end{tabular}


bioRxiv preprint doi: https://doi.org/10.1101/2020.02.03.922864; this version posted April 25, 2020. The copyright holder for this preprint (which was not certified by peer review) is the author/funder, who has granted bioRxiv a license to display the preprint in perpetuity. It is made available under aCC-BY-NC-ND 4.0 International license.

\begin{tabular}{|l|l|l|l|}
\hline 26 & K07277 & $\operatorname{tr|Q5ZY66~}$ & Outer membrane protein assembly factor BamA \\
\hline 27 & K09014 & tr|Q5ZXX9 & ABC transporter, permease \\
\hline 28 & K02198 & tr|Q5ZX71 & Cytochrome c-type biogenesis protein CcmF \\
\hline 29 & K02558 & tr|Q5ZUP0 & $\begin{array}{l}\text { UDP-N-acetylmuramate-L-alanyl-gamma-D-glutamyl- } \\
\text { meso-2,6-diaminoheptandioate ligase }\end{array}$ \\
\hline
\end{tabular}

Supplementary Table 2: Functional family classification of the hypothetical proteins by SVMProt server

\begin{tabular}{|l|l|l|l|l|l|}
\hline S. no. & Accession no. & KO assignment & Family name & $\begin{array}{l}\text { Probability } \\
(\%)\end{array}$ & GO category \\
\hline 1 & sp|Q5ZYZ0 & K09822 & Iron-binding & 98.4 & GO:0005506 \\
\hline 2 & tr|Q5ZS92 & K07007 & Iron-binding & 98.9 & GO:0005506 \\
\hline 3 & tr|Q5ZYU2 & K06915 & All DNA-binding & 85.4 & GO:0003677 \\
\hline
\end{tabular}

Supplementary Table 3: Templates used for homology modeling by EasyModeller 4.0 


\begin{tabular}{|c|c|c|c|}
\hline Protein accession no. & PDB ID & Identity (\%) & Query cover \\
\hline & 4R40 & 41 & 95 \\
\hline sp|Q5ZV69 & 3IAX & 40 & 99 \\
\hline & 1C5K & 40 & 99 \\
\hline
\end{tabular}

Supplementary Table 4: ProtParam analysis of LEGPH protein TolB

\begin{tabular}{|c|c|c|c|c|c|c|c|c|}
\hline $\begin{array}{c}\text { Viral } \\
\text { Proteins }\end{array}$ & $\begin{array}{c}\text { Accession } \\
\text { ID }\end{array}$ & $\begin{array}{c}\text { Molecul } \\
\text { ar } \\
\text { Weight }\end{array}$ & $\begin{array}{c}\text { Instabili } \\
\text { ty Index }\end{array}$ & $\begin{array}{c}\text { Aliphati } \\
\text { c Index }\end{array}$ & $\begin{array}{c}\text { Theoretic } \\
\text { al pI }\end{array}$ & $\begin{array}{c}\text { No. of } \\
\text { Amino } \\
\text { acids }\end{array}$ & $\begin{array}{c}\text { Estinctio } \\
\text { n Co- } \\
\text { Efficient }\end{array}$ & Gravy \\
\hline TolB_LEGPH & Q5ZV69 & $\begin{array}{c}45387.0 \\
6\end{array}$ & 38.09 & 89.81 & 8.67 & 419 & 34380 & -0.204 \\
\hline
\end{tabular}

Supplementary Table 5: Identified epitope clusters among top CTL, HTL and BCL epitopes

\begin{tabular}{|c|c|c|}
\hline CTL epitope clusters & HTL epitope clusters & BCL epitope clusters \\
\hline RIISLFLLLFT & TPKIYDVDLSSGSMKQLTFG & SGPQGANSQSSV \\
\hline TSGRGGSPQVY & LTFGNSIDTEPRYSPDG & $\begin{array}{l}\text { AREGDVQEPAWSPY } \\
\text { SWSPNGK }\end{array}$ \\
\hline QVIALDLELTQ & FTSGRGGSPQVYRLSLA & $\begin{array}{l}\text { SGRGGSP } \\
\text { SFEKKKA }\end{array}$ \\
\hline IGVQNTGGGP & YSLEVADADGHNPQS & IDTEPRYSPDG \\
\hline LPAREGDVQ & RVTFEGNYNARASYT & $\begin{array}{l}\text { ADGQISR } \\
\text { IISLFLLLFTGQVIAL }\end{array}$ \\
\hline DVDLSSGSMK & GGRSRYSLEVADADG & $\begin{array}{l}\text { DLE } \\
\text { GQHLAVVLSK }\end{array}$ \\
\hline
\end{tabular}


bioRxiv preprint doi: https://doi.org/10.1101/2020.02.03.922864; this version posted April 25, 2020. The copyright holder for this preprint (which was not certified by peer review) is the author/funder, who has granted bioRxiv a license to display the preprint in perpetuity. It is made available under aCC-BY-NC-ND 4.0 International license.

\begin{tabular}{|l|l|l|}
\hline TFGNSIDTE & ISGPQGANSQSSVST & YSPDGRS \\
& VIALDLELTQGINSA & \\
\hline
\end{tabular}

